
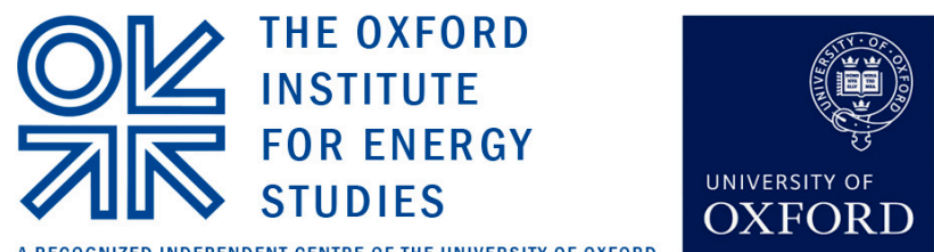

A RECOGNIZED INDEPENDENT CENTRE OF THE UNIVERSITY OF OXFORD

\title{
The Gas Relationship between the Baltic States and Russia: politics and commercial realities
}

\section{Agnia Grigas $^{1}$}

\author{
NG 67
}

\section{October 2012}

\footnotetext{
${ }^{1}$ Agnia Grigas (née Baranauskaitè) has a decade of experience in business and academia working as a development and political risk consultant for corporations and governments. She is the author of The Politics of Energy and Memory between the Baltic States and Russia (Ashgate Publishing, forthcoming ) and holds a $\mathrm{PhD}$ in international relations from the University of Oxford.
} 
The contents of this paper are the author's sole responsibility. They do not necessarily represent the views of the Oxford Institute for Energy Studies, of any of the Institute's members, and/or of the author's other affiliations.

Copyright $₫ 2012$

Oxford Institute for Energy Studies

(Registered Charity, No. 286084)

This publication may be reproduced in part for educational or non-profit purposes without special permission from the copyright holder, provided acknowledgment of the source is made. No use of this publication may be made for resale or for any other commercial purpose whatsoever without prior permission in writing from the Oxford Institute for Energy Studies.

ISBN 978-1-907555-58-9 


\section{Acknowledgements}

I would like to thank Jonathan Stern, Chairman and Senior Research Fellow of the Natural Gas Programme at the Oxford Institute for Energy Studies, for having read, commented and given me guidance on this study. I would also like to thank editor John Elkins, cartographer David Sansom, and my research assistant Sabina Karmazinaite. 


\section{Preface}

The OIES Natural Gas Programme has published detailed studies of gas relationships between Russia and all European and CIS countries, with the exception of the Baltic States: Estonia, Latvia and Lithuania. While Russian exports to the Baltic countries are small in numerical terms, they are highly significant politically and in the energy balances of those countries.

Agnia Grigas' book on Baltic energy relations with Russia is the first work of which I am aware which gives a detailed account of the energy relationship in the post-Soviet period, distinct from the ideological and political commentary which characterises most of the literature on these issues, utilising original sources in the languages of the region. While Baltic gas markets are small, they have a number of fascinating and complex attributes including: huge storage capacity in Latvia; pipeline interconnections between the countries; Russia's reliance on Lithuania for transit to Kaliningrad; substantial Gazprom shareholdings (much larger than anywhere else in Europe) in major gas companies; and intermediaries marketing Russian gas. Moreover Russian oil relations with the Baltic states provided an early example of Moscow's determination to eliminate energy transit across countries unwilling to allow Russian ownership and control of transportation assets; a determination which was subsequently continued in the gas sector.

20 years after the end of the Soviet Union the Baltic States remain completely dependent on Russian gas, despite an apparent conviction throughout the region that this relationship has been, and remains, economically exploitative and a continuation of Soviet subjugation. This study reviews the evolution of Russian gas relations with the Baltic States, including their (so far unsuccessful) determination to diversify their supplies by importing LNG. It has taken a little while to reach publication, but over the past few months, disagreements between Gazprom and Baltic governments over ownership of gas networks, and antitrust proceedings brought by DG COMP against Gazprom, have given it a very topical significance. I am very grateful to Agnia Grigas for bringing the paper to a successful conclusion in the midst of all her other commitments.

Jonathan Stern 


\section{Contents}

INTRODUCTION....................................................................................................................

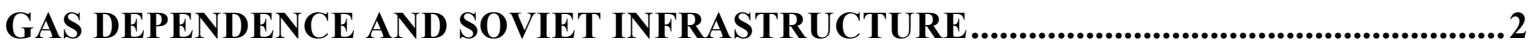

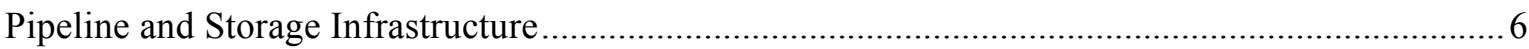

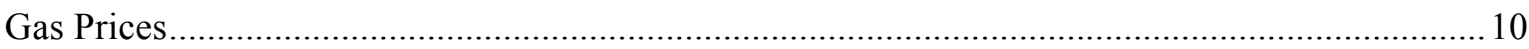

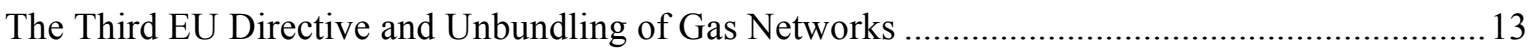

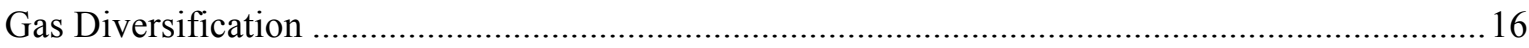

DOMESTIC ACTORS IN THE BALTIC GAS SECTOR .........................................................20

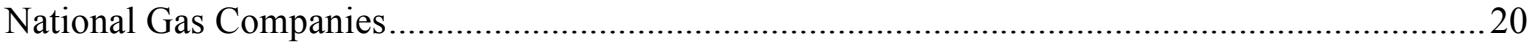

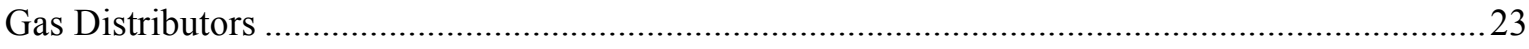

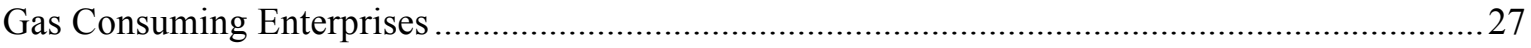

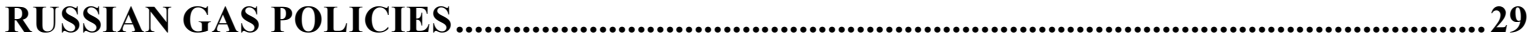

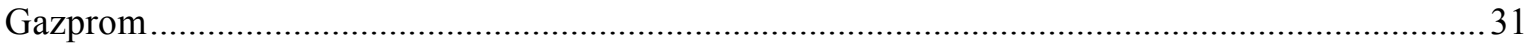

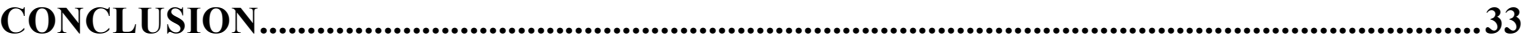

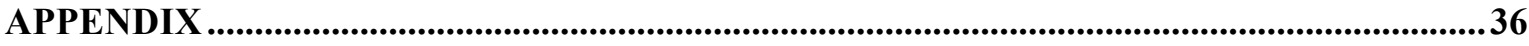

THE PRIVATIZATION OF BALTIC GAS COMPANIES - AN HISTORICAL OVERVIEW

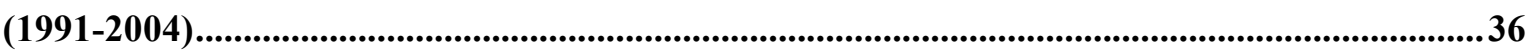

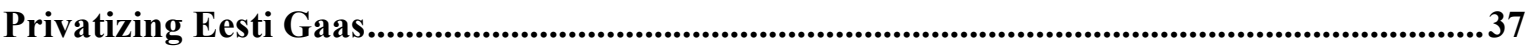

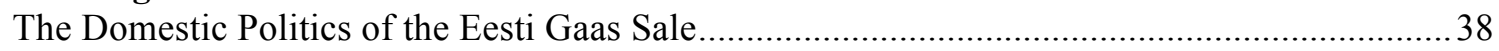

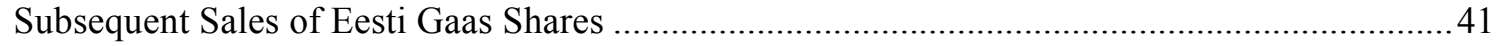

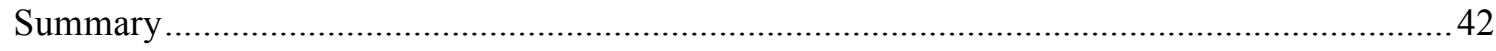

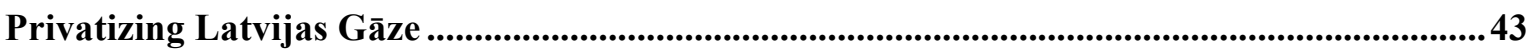

The Domestic Politics of the Latvijas Gāze Sale in the 1990s ....................................................4

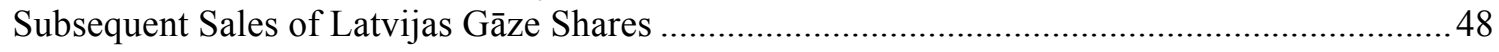

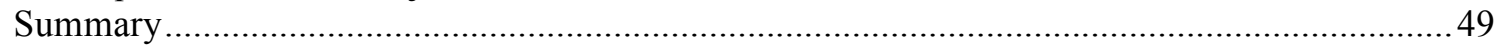

Privatizing Lietuvos Dujos ..........................................................................................................................49

The Domestic Politics of the Lietuvos Dujos Privatization .......................................................51

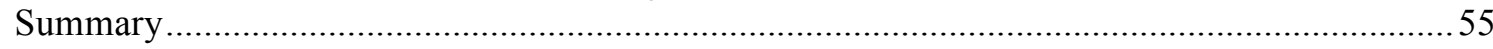




\section{Tables}

Table 1: Gas as a percentage of Baltic States' energy consumption (gross inland consumption).

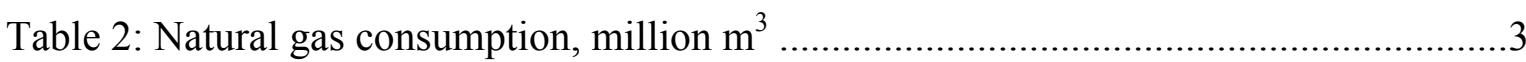

Table 3: Energy import dependency amongst EU States and gas import sources (2010) .....5

Table 4: Gazprom shareholdings in Baltic national gas companies ...................................21

Table 5: Main privatization stages of Eesti Gaas............................................................42

Table 6: Main privatization stages of Latvijas Gāze...........................................................48

\section{Maps}

Map 1: Energy and gas pipeline infrastructure in the Baltic Region .................................... 


\section{Introduction}

Much has been written about the EU-Russia energy relationship, especially as new EU member states are extremely dependent on Russia for gas imports and are therefore anxious to diversify their energy sources. The three Baltic states of Estonia, Latvia, and Lithuania are a unique case within the $\mathrm{EU}$, as they are gas islands and are also completely dependent on Russia for gas imports. As a result, Baltic-Russian relations as well as Baltic domestic politics and economies remain strongly characterised by this factor of acute gas dependence. This paper is a revised excerpt from my doctoral thesis at the University of Oxford $^{2}$ and is the basis of two chapters in my upcoming book The Politics of Energy and Memory between the Baltic States and Russia. ${ }^{3}$ The doctoral thesis and the upcoming book examine Baltic-Russian relations since the 1990s in the oil and gas sectors and the tensions stemming from the legacy of Soviet occupation. This paper focuses specifically on the politics of gas between the Baltic countries and Russia since the 1990s. By comparing and contrasting the gas policies of the three Baltic states as well as their domestic gas conditions, I argue that the Baltic-Russian gas relationship is shaped by politics on one hand and commercial realities on the other.

This paper examines contemporary Baltic-Russian gas relations by providing an analysis of the structural conditions and the key actors in the Baltic gas sector. First, an overview of the gas sector is provided paying special attention to Soviet-era infrastructure, gas prices, unbundling policies, and diversification efforts. Second, the main domestic gas actors such as national gas companies, distributors, and main gas consuming enterprises are presented. An analysis of Russia's and Gazprom's gas policies towards the Baltic states and its 'near abroad' completes the picture. The appendix to the paper provides historical case studies of Gazprom's privatization of the three Baltic national gas companies Eesti Gaas, Latvijas Gāze, and Lietuvos Dujos in 1991-2004 in order to demonstrate the interplay of different Baltic gas structural factors and actors in the early post-Soviet period.

\footnotetext{
${ }^{2}$ Grigas 2010.

${ }^{3}$ Grigas 2013.
} 


\section{Gas Dependence and Soviet Infrastructure}

The Baltic states are dependent on Russia for key sources of energy such as gas, oil, and even electricity. However, the gas dependency - at $100 \%-$ is the most acute. A comparison with the oil sector highlights the unique conditions of the gas sector. First, the Baltic states can import gas only through Russian pipelines. In contrast, oil is traded internationally and the Baltic states have the capacity to import non-Russian oil and oil products via their oil terminals on the Baltic Sea coast. Second, unlike the case of oil, Russia does not depend on Baltic territories for gas transit to other markets. A further difference is that there has been considerable Russian investment in the Baltic gas sectors; by way of contrast, there has been greater success in resisting Russian investment in the oil sector.

The importance of gas in the domestic energy mix of the Baltic countries has contributed to greater vulnerability vis-à-vis Russia. In the Baltics, the majority of gas is used for the production of heat and electricity. In $2010,57 \%$ of total gas used in Estonia was for power generation, $65 \%$ in Latvia, and $55 \%$ in Lithuania. Industry used about $7 \%$ of total gas consumption in Estonia in 2010, $17 \%$ in Latvia, and $35 \%$ (including production of fertilizers) in Lithuania. Household consumption of gas, particularly for heating in the winter months, made up $6 \%$ of total gas used in Estonia in 2010, $9 \%$ in Latvia, and $6 \%$ in Lithuania. $^{4}$

Table 1: Gas as a percentage of Baltic States' energy consumption (gross inland consumption)

\begin{tabular}{|l|c|c|c|c|c|}
\hline & $\mathbf{2 0 1 0}$ & $\mathbf{2 0 0 7}$ & $\mathbf{2 0 0 3}$ & $\mathbf{1 9 9 9}$ & $\mathbf{1 9 9 5}$ \\
\hline Estonia & $9.2 \%$ & $13.3 \%$ & $12.3 \%$ & $11.5 \%$ & $10.9 \%$ \\
\hline Latvia & $32.2 \%$ & $29.4 \%$ & $33.4 \%$ & $25 \%$ & $21.8 \%$ \\
\hline Lithuania & $36.3 \%$ & $31.5 \%$ & $26 \%$ & $23 \%$ & $23.3 \%$ \\
\hline
\end{tabular}

Source: Eurostat, Gross inland energy consumption, 2012.

Table 1 shows that the share of gas in total inland energy consumption has generally increased with economic development in Latvia and Lithuania since 1995, from approximately $20 \%$ to approximately $30 \%$ in the 2000 s. Estonia's gas consumption has ranged between $9 \%$ and $13 \%$ throughout the last decade. However, when comparing the

\footnotetext{
4 "Consumption of energy resources in Latvia in 2010"; Valstybinè kainų ir energetikos kontrolès komisija, "Lietuvos Respublikos elektros energijos ir gamtinių dujų rinkų metiné ataskaita Europos Komisijai", Vilnius, 2011, p.84-85; Findlater and Noël 2010, p.11.
} 
volumes consumed in 1990 and 2011 (Table 2) it can be seen that the volume of gas used in the Baltics has nearly halved due to the sharp decline in Soviet-era industry: from 10,263 million $\mathrm{m}^{3}$ in 1990 to 5,634 million $\mathrm{m}^{3}$ in 2011 .

Table 2: Natural gas consumption, million $\mathbf{m}^{3}$

\begin{tabular}{|l|c|c|c|c|c|c|c|}
\hline & $\mathbf{1 9 9 0}$ & $\mathbf{1 9 9 4}$ & $\mathbf{1 9 9 8}$ & $\mathbf{2 0 0 2}$ & $\mathbf{2 0 0 6}$ & $\mathbf{2 0 1 0}$ & $\mathbf{2 0 1 1}$ \\
\hline Estonia & 1516 & 646 & 738 & 743 & 1009 & 702 & 631 \\
\hline Latvia & 2937 & 1028 & 1299 & 1609 & 1756 & 1821 & 1604 \\
\hline Lithuania & 5810 & 2150 & 2192 & 2713 & 3068 & 3115 & 3399 \\
\hline TOTAL & 10263 & 3824 & 4229 & 5065 & 5833 & 5638 & 5634 \\
\hline
\end{tabular}

Source: National statistics agencies Eesti Statistika, Latvijas Statistika, Lietuvos Statistikos Departamentas as of August 2012.

In recent years, several changes have occurred in the pattern of gas consumption and more changes are on the horizon. In Estonia, due to the economic slowdown of 2008-2010, consumption of gas has dropped both as percentage of the total energy mix and in volume from the peaks of 2007 of $13 \%$ of primary energy consumption and 1003 million $\mathrm{m}^{3} .^{5} \mathrm{EU}$ emissions regulations that have granted Estonia exemptions until now are requiring Estonia to reduce its emissions from its domestic oil shale production by 2013. This will increase Estonia's reliance on gas post 2013. In 2010, oil shale was utilized in the production of more than $90 \%$ of Estonia's electricity. ${ }^{6}$ The 2004 and 2009 closures of the Lithuanian nuclear power plant reactors further increased the reliance on gas in Lithuania, where gas rose from $28 \%$ of total energy consumption in 2008 to $36 \%$ by 2010 . Yet, the overall volumes of gas used dropped in Lithuania from 2008 to 2010 due to economic slowdown of these years until they rebounded in $2011 .^{7}$ In Latvia, which also used to import electricity from Lithuania, the reliance on gas rose slightly from $29 \%$ in 2008 to $32 \%$ in 2010. In terms of volume of gas consumed, after a slump due to the economic crisis of 2008 and 2009, a record high of 1821 million $\mathrm{m}^{3}$ was reached in 2010 that had been exceeded only in 1992.

\footnotetext{
${ }^{5}$ Data from Eesti Gaas, National statistics agencies Latvijas statistika, Lietuvos statistikos departamentas.

${ }^{6}$ Iklaa 2010.

${ }^{7}$ Statistical Yearbook of Lithuania 1996 and 2008 (issued by Statistics Lithuania, <www.stat.gov.lt>). Statistical Yearbook of Latvia 1996 and 2008 (issued by Central Statistical Bureau Of Latvia, $<$ www.csb.gov.lv>).
} 
Naturally the total dependence on Russia and the importance of gas in the domestic energy mix raises a number of questions for overall Baltic energy policy. Energy dependence and energy security are two main factors to consider in the Baltic context. Energy dependence demonstrates the proportion of imported energy sources in a country? $\mathrm{s}$ energy balance; while energy security demonstrates the degree of access to energy sources that are reliable, affordable, deployable, and politically and environmentally sustainable. ${ }^{8}$ Energy import dependence is often perceived as a security risk because it exposes national economies and politics to external stresses and increases trade imbalances for energy importing states. 9 When examining the Baltic energy sector, it is important to highlight that it has not been high levels of dependence on imported energy to satisfy domestic consumption which has caused controversy. Rather, the policy agenda has been dominated by questions over the security implications of the sources of imported energy. The percentage of imported energy sources (gas, oil, electricity, and other) as a total of domestic energy consumption is very different among the three Baltic states. In 2010 Latvia's energy import dependency rate (the percentage of domestic energy needs met with imports) of $41.6 \%$ is slightly below the EU average of $52.7 \%$. Estonia, in 2010 was dependent on external sources for only $12.9 \%$ of its energy, significantly below the EU average. This is because Latvia met some of its energy needs through domestic hydropower, Estonia from domestic oil shale. Lithuania until recently relied on nuclear power, but since the closure of both nuclear reactors, in 2010 its import dependence rose significantly above the EU average to $81.9 \%$.

Energy import dependence in itself does not create energy security risks; lack of diversification is the main concern. ${ }^{10}$ Amongst the measures proposed by the EU on external energy security, diversification is the most prominent. According to EU proposals energy security can be improved by diversification of imported energy sources, routes, and suppliers. ${ }^{11}$ Energy security of a state is determined not only by the level of diversification but also the sources of these undiversified imports. If energy sources are undiversified and imported from a hostile or potentially hostile state, high import dependence increases vulnerability. Lastly, in the gas sector access to storage is also a crucial element in security.

The Baltic states import the majority of their energy from Russia which is perceived by the Baltic governments as a potentially hostile state. Baltic energy dependence is even greater in the gas than the oil sector since $100 \%$ of the three Baltic states' total gas consumption is

\footnotetext{
${ }^{8}$ Roberts 2008.

${ }^{9}$ Roberts 2008 .

${ }^{10}$ Motieka, Vaičiūnas, and Gaidytė 2008, p.13.

${ }^{11}$ Geden 2009, p. 17.
} 
supplied by Russia. Thus, even though Estonia's $12.9 \%$ dependence on energy imports is amongst the lowest in the EU, Estonia is wholly dependent on Russia for its gas imports. And since political relations with Moscow are often tense, Estonia is one of the most energy-vulnerable states in the EU. On the other hand, Latvia's 2010 gas import dependence of $61.8 \%$ does not fully reflect its vulnerability because the figure takes into account that it can store gas for several years without importing all its gas requirements every year. However, Russia is the only source of imports. Compared to other EU member states, the Baltic countries most resemble Bulgaria, Romania, Slovakia, and Finland, which are likewise vulnerable due to their complete dependence on Russia for gas. ${ }^{12}$ Other states that rely on Russia for the majority of their gas imports include Greece, Austria, and former Socialist bloc countries such as Hungary and Poland.

Table 3: Energy import dependency* amongst EU States and gas import sources (2010)

\begin{tabular}{|c|c|c|c|}
\hline EU State & $\begin{array}{c}\text { Total Energy } \\
\text { Import } \\
\text { Dependency }(\% * * \\
)\end{array}$ & $\begin{array}{c}\text { Natural Gas } \\
\text { Import } \\
\text { Dependency }(\%)\end{array}$ & $\begin{array}{c}\text { Primary Import Sources of } \\
\text { Natural Gas }\end{array}$ \\
\hline EU (27 countries) & 52.68 & 63,38 & \\
\hline Cyprus & 100 & 0 & $\begin{array}{l}\text { Does not import gas and gas is } \\
\text { not used as an energy source }\end{array}$ \\
\hline Malta & 100 & 0 & $\begin{array}{l}\text { Does not import gas and gas is } \\
\text { not used as an energy source }\end{array}$ \\
\hline Luxembourg & 96.82 & 100 & Norway. Russia \\
\hline Ireland & 85.62 & 93.4 & $\begin{array}{l}\text { United Kingdom (only source of } \\
\text { import) }\end{array}$ \\
\hline Italy & 83.78 & 90.51 & Algeria. Russia \\
\hline LITHUANIA & 81.92 & 99.71 & Russia (only source of import) \\
\hline Belgium & 76.84 & 99.01 & The Netherlands. Norway \\
\hline Spain & 76.69 & 99.24 & Algeria, Nigeria and others \\
\hline Portugal & 75.45 & 100.37 & Nigeria, Algeria \\
\hline Greece & 69.11 & 99.9 & Russia, Algeria. Turkey \\
\hline Slovakia & 63.13 & 99.92 & Russia (only source of import) \\
\hline
\end{tabular}

\footnotetext{
${ }^{12}$ Motieka, Vaičiūnas, and Gaidytė 2008, pp.12-13.
} 


\begin{tabular}{|l|c|c|l|}
\hline Austria & 61.82 & 74.44 & Russia, Norway. Germany \\
\hline Germany & 59.78 & 81.89 & $\begin{array}{l}\text { Russia, } \\
\text { Netherlands }\end{array}$ \\
\hline Hungary & 58.26 & 78.71 & Russia and others \\
\hline France & 49.3 & 92.98 & Norway. Russia, Algeria \\
\hline Slovenia & 49.3 & 99.3 & Russia, Algeria and others \\
\hline Finland & 48.14 & 100 & Russia (only source of import) \\
\hline LATVIA & $\mathbf{4 1 . 6 2}$ & $\mathbf{6 1 . 7 8}$ & Russia (only source of import) \\
\hline Bulgaria & 40.33 & 95.08 & Russia (only source of import) \\
\hline Sweden & 36.53 & 100 & $\begin{array}{l}\text { Denmark (only source } \\
\text { import) }\end{array}$ \\
\hline Poland & 31.51 & 69.3 & Russia. Germany \\
\hline Netherlands & 30.69 & -61.59 & Gas exporting state \\
\hline United Kingdom & 28.27 & 37.69 & $\begin{array}{l}\text { Norway, the Netherlands. } \\
\text { Belgium }\end{array}$ \\
\hline Czech Republic & 25.6 & 85.38 & Russia, Norway \\
\hline Romania & 21.66 & 16.83 & Russia (only source of import) \\
\hline ESTONIA & $\mathbf{1 2 . 9 3}$ & $\mathbf{1 0 0}$ & Russia (only source of import) \\
\hline Denmark & -18.21 & -68.31 & Gas exporting state \\
\hline
\end{tabular}

Source: Eurostat, Energy dependence, 2012. International Energy Agency country reports, <www.iea.org>, 2012. Energy Delta Institute country gas profiles, <www.energydelta.org>, 2012.

Notes: *Energy import dependency demonstrates what percentage of a state's energy needs are met by imported energy sources. The rest of energy needs are met by domestic production.

$* * \%$ of net imports in gross inland consumption.

\section{Pipeline and Storage Infrastructure}

The Baltics are more vulnerable in terms of gas than many other EU states not only because of their import dependence on a single and potentially hostile source, but due to their gas transport and delivery infrastructure. As in Finland, Bulgaria, Serbia and other Balkan countries, Baltic gas transport and infrastructure was built in the Soviet era. Russian gas is brought to the Baltic states via Gazprom-owned pipelines. As Map 1 shows, gas pipelines supplying Estonia from northern Russian territory first pass through Latvia 
before they arrive in Tallinn. Latvia is fed through two primary pipelines. One comes directly from Russian territory and continues to Estonia; the other passes through Belarus and Lithuania. Lithuania is supplied by a pipeline that arrives from Belarus and continues onward to the Russian territory of Kaliningrad. Due to the extant gas infrastructure and the lack of alternative links with states which could supply alternative sources of gas, the Baltic states are called 'gas islands. ${ }^{13}$ In addition, they do not have liquefied natural gas (LNG) terminals which would enable imports by sea routes.

\section{Map 1: Energy and gas pipeline infrastructure in the Baltic Region}

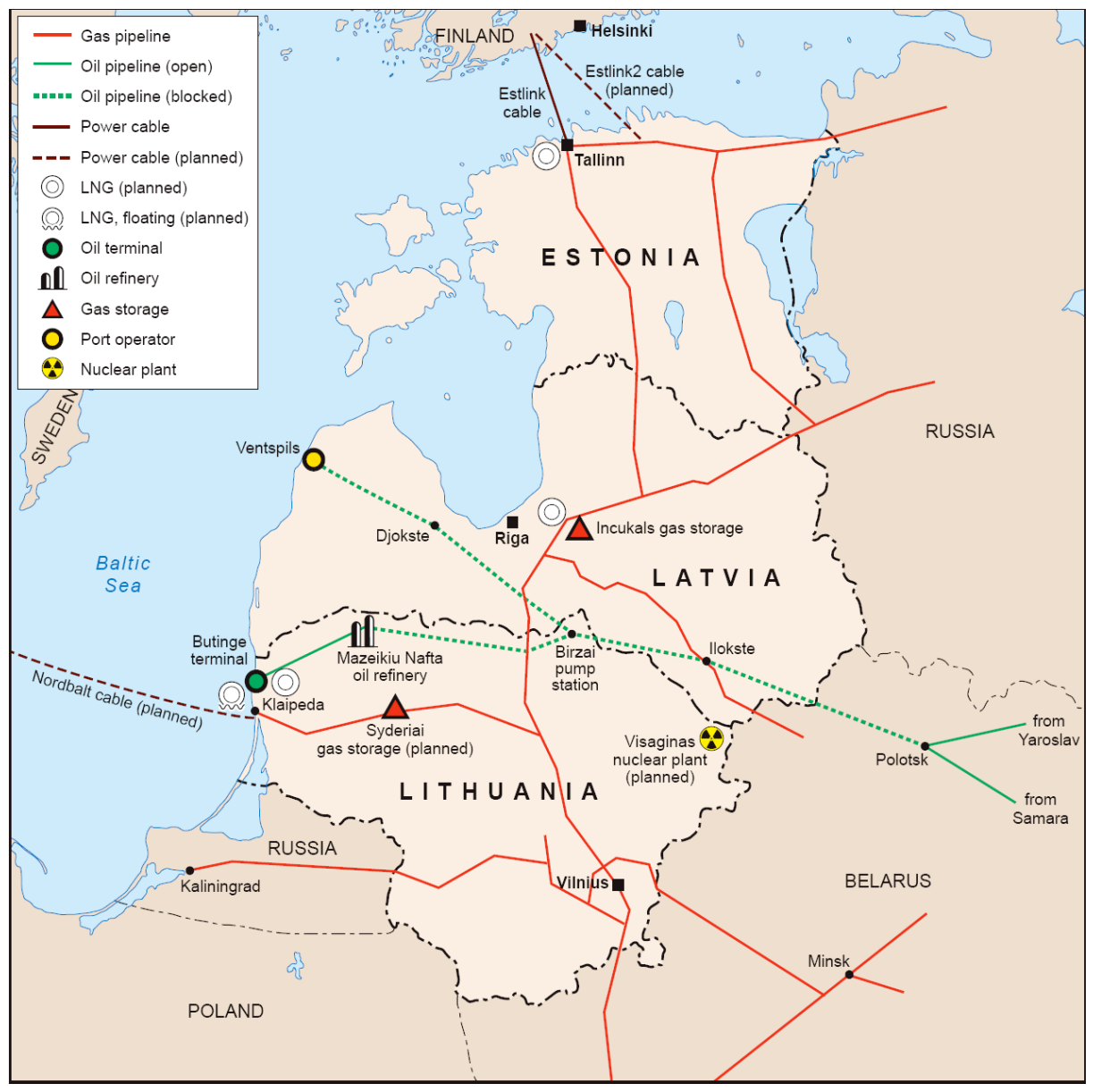

Another dimension is that the Baltic countries are not transit states for Russian gas exports to European markets. As a consequence, and unlike the former Warsaw Pact states or even Ukraine, the Baltics cannot rely on pressure from European states further down the supply

\footnotetext{
${ }^{13}$ Riley 2009, p.3.
} 
line to ensure that Russia keeps supplies flowing. Arguably, Moscow would be more hesitant about disrupting supplies to its larger European clients ${ }^{14}$ because of the need to preclude a coordinated EU response. As the Russian-Ukrainian gas crisis of January 2009 demonstrated, when Moscow reduced gas supply to Ukraine, a shortage was felt immediately in several EU countries supplied by pipelines which pass through Ukrainian territory. EU member states responded by seeking to coordinate an EU-level response to Moscow and Kiev during an informal meeting of the Foreign Ministers in Prague in January 2009.

The Baltic elites fear that if they were to face gas cuts, there would not be a substantial coordinated EU response because no other EU states would be impacted. ${ }^{15}$ Some of these fears are unfounded since it is unlikely that there would be no response from EU or NATO if gas supplies to their member states were interrupted. However with a protracted crisis in the EU, and the problems the EU generally experiences in coordinating policy towards Russia when the national interests of the large member states are not affected, any BalticRussian gas conflict might not receive top priority.

Of the Baltic states, only Lithuania serves as a gas transit state for Russian gas, to the Russian territory of Kaliningrad, which is physically separated from Russia by Belarusian and Lithuanian lands. Since the 1990s, gas transit to Kaliningrad served as a sort of guarantee of gas supply for Lithuania since any interruption would directly affect Kaliningrad. Kaliningrad itself is an energy island and does not receive gas, oil, or electricity other than through Lithuanian territory. Vilnius has used Kaliningrad's reliance on Lithuania for gas transit and electricity supply as a bargaining tool with Moscow on several occasions. ${ }^{16}$ However, as the next section on Russian gas policies will demonstrate in greater depth, in the 2000s Moscow pursued a strategy of making gas supply to Kaliningrad independent from transit through Lithuania. The prime aspects of this strategy include completion of gas storage facilities in Kaliningrad in two stages (by 2010 and by 2015), ${ }^{17}$ as well as plans to link Kaliningrad with the Nord Stream gas pipeline which delivers Russian gas via the Baltic Sea directly to Germany, thereby bypassing the Baltic

\footnotetext{
${ }^{14}$ Riley 2009, p.3.

${ }^{15}$ Interviews with Estonian, Latvian, and Lithuanian diplomats in spring and summer 2009.

${ }^{16}$ Drezner 1999, p.217.

${ }^{17}$ In 2010 a small storage facility that could provide Kaliningrad a month of supply of gas was completed. A large storage facility that could provide a year's worth of gas supplies to Kaliningrad will become operational by 2015. Information provided by the Lithuanian Ministry of Foreign Affairs, 2009.
} 
states. Connecting Kaliningrad to Nord Stream and increasing gas storage would make the Russian territory completely independent from gas transit through Lithuania. This, in turn, could make Lithuania subject to a Moscow gas cut off without any consequences for the Russian territory.

As with Lithuania's gas transit to Kaliningrad, Latvia's comparative advantage and guarantee of gas supply is the country's storage facility. The Inčukalns Underground Gas Storage is the only significant storage facility in the region, serving primarily Latvia but also Lithuania, Estonia, and northwest Russia in the winter period. ${ }^{18}$ Inčukalns capacity totals 4.4 billion $\mathrm{m}^{3}$ of which 2.3 billion $\mathrm{m}^{3}$ is active, and there is potential to increase it. The present capacity exceeds Latvia's annual consumption of gas, which in 2010 was 1.8 billion $\mathrm{m}^{3}{ }^{19}$ Inčukalns increases Latvian gas security because it can provide Latvia and even Estonia and Lithuania with supply in the case of interruptions.

However, there is uncertainty among Baltic elites about the extent to which this facility makes Latvia truly independent of Gazprom. First, Inčukalns is owned by Latvijas Gāze, $50 \%$ of whose shares are in turn owned by Gazprom and another Russian company, Itera Latvija. Second, the Inčukalns facilities were not designed with any emergency considerations in mind, but rather to ensure constant gas supply and meet the needs of national gas distributor Latvijas Gāze. Third, current gas supply agreements effectively exclude the possibility of access by a third party to Inčukalns. ${ }^{20}$ Thus, Latvian storage facilities (developed in close cooperation with and partially owned by Gazprom) highlight Gazprom?s stake in the Latvian energy sector. Nevertheless, because the storage is operated by Latvijas Gāze on Latvian territory it would be extremely difficult for Russia or Gazprom to prevent the gas from being released if this were ordered by the Latvian government.

Latvia's gas storage capability has some (albeit limited) impact on the gas security of Estonia and Lithuania because resources could be provided from Inčukalns in the event of a gas supply interruption. ${ }^{21}$ Lithuania relied on Latvia during the Russian-Belarusian gas conflict, when gas supply to Lithuania was also cut off in mid-February 2004. During the two day hiatus, Lithuania was able to access 5 million $\mathrm{m}^{3}$ of the required 12 million $\mathrm{m}^{3}$ via

\footnotetext{
${ }^{18}$ Sprūds 2009, p.228.

${ }^{19}$ Latvijas statistika

${ }^{20}$ Lejiņš 2010.

21 "Energetikos sektoriaus apžvalga".
} 
the pipeline connecting Lithuania and Latvia. ${ }^{22}$ Although the gas storage capacity of Inčukalns at 2.3 billion $\mathrm{m}^{3}$ could not meet the annual demand of the three Baltic states, which consume nearly 5 billion $\mathrm{m}^{3}$ annually, Estonia and Lithuania could rely on gas supply from Latvia to cover their needs for a few months until the crisis would be resolved. For this reason, Lithuania's energy security strategy contains plans to increase the country's stored gas reserves at Inčukalns by 200 million $\mathrm{m}^{3}$, which would allow the demands of residential consumers and power enterprises to be met for a period of two winter months. ${ }^{23}$ This would alter the energy security equation considerably since the ability to withstand an interruption during the winter months would significantly reduce the hardship for the Lithuanian population and economy, and would diminish the gains Russia might seek from such action. Since 2009, Lithuania has been considering building its own gas storage capacity in Syderiai - both in order to have its own larger gas reserves and because of concern about over-reliance on Inčukalns, which, as noted, is partly owned by Gazprom. $^{24}$

\section{Gas Prices}

In the recent years, the price the Baltic states pay for Russian gas is one the most highly politicized topics among the Baltic media and elites. In the pre-independence era, the Baltic Soviet Republics received gas at below market prices, mostly in the form of barter. The energy relationship changed following independence. In the early 1990s, the Baltic states still benefited from lower gas prices than Western European states but prices gradually increased by the 2000s. The increase in gas prices was particularly notable after accession to EU and NATO, from 2005 to 2007, when the price of gas imports rose to 2.4 times their 2005 rates. ${ }^{25}$ Prices continued to increase, and according to the Chairman of the Board of Latvijas Gāze, Adrians Dāvis, reached Western European levels in $2008 .{ }^{26}$ The fact that the Baltic states continued to benefit from concessionary gas prices for nearly 17 years after independence, even as EU member states, clearly challenges the widespread Baltic perception of price discrimination.

\footnotetext{
22 Janeliūnas 2009, p.190.

23 "Development of the Lithuanian Energy Strategy after the Closure of Ignalina NPP".

${ }^{24}$ Interview with senior strategist of Homeland Union political party. Vilnius, June 2010.

${ }^{25}$ Janeliūnas 2009, p.198. Oil prices - on which gas prices are based (with a lag) - increased from $\$ 38-72 / \mathrm{bbl}$ in the period 2004-07 (BP 2012, p.15.)

${ }^{26}$ Pavuk 2007. Łoskot-Strachota and Pełczyńska-Nałęcz 2008, p.12.
} 
It is nearly impossible to get accurate and consistent data of current prices paid by the Baltic national gas companies and gas distributors. The gas supply contracts negotiated between Gazprom and the Baltic companies are considered commercially confidential, and this is no different from other European gas contracts. However, in the Baltics the issue goes beyond the commercial realm into the political, because the price of gas has a tremendous impact on Baltic households who rely on gas for heating in the winter months. According to the International Energy Agency, whilst Germans spend 3\% of their post-tax income for home energy use, Central and Eastern European residents spend 10 to $15 \%$. The fact that oil prices - and therefore gas prices on which they are based - have increased consistently since the mid 2000s, and that the Baltic states have experienced a severe economic downturn in the late 2000 s, makes the issue of gas prices highly sensitive for the public, and thus of great concern for Baltic political parties.

Baltic media and government officials consistently argue that Russia uniquely discriminates against them in terms of gas pricing in comparison to other neighbouring states and fellow EU members. Reports continuously claim that fellow former Soviet republics such as Ukraine and Belarus pay lower gas prices to Gazprom and that Moscow sets prices in a politicized fashion. ${ }^{27}$ However, this is incorrect at least in relation to CIS countries in 2012 when Ukraine was paying \$420/mcm (around \$11/MMbtu) and Belarus $\$ 166 / \mathrm{mcm}$ (around $\$ 4.6 / \mathrm{MMbtu}$ ) which were some of the highest and lowest prices in Europe at that time. ${ }^{28}$

There is also a belief in the Baltic states that they pay higher prices for gas than other EU states such as Germany by $\$ 40$ to $\$ 80 / \mathrm{mcm}$ even though the greater distance and higher transit costs would lead one to expect that final gas prices further West would be higher. ${ }^{29}$ However, it is difficult to determine whether these media reports are accurate. Second, comparing the prices paid by the Baltics and Germany is analytically difficult Gazprom sets prices individually for each European country based on netback market pricing principles which are linked to the price of oil. The final price depends on a set of factors such as the price of oil over the last 6-9 months, a price formula agreed between Gazprom and the destination market, local transportation, storage and distribution costs, national

\footnotetext{
${ }^{27}$ Information from Lithuanian Ministry of Energy, 2011.

${ }^{28}$ However, the situation changes from year to year and the prices of Russian gas in Russian contracts with CIS countries are considerably more transparent than those in European contracts. For an account of CIS gas prices since 2000, see Henderson, Pirani and Yafimava 2012, pp.178-223.

${ }^{29}$ Girdvainis 2012. Sytas 2012.
} 
taxes, and the end price adjustment policy of the national regulator. ${ }^{30}$ Thus it is plausible that German customers have traditionally paid lower gas prices because of the different characteristics of their gas and energy markets. Overall it remains very difficult to demonstrate conclusively that Gazprom practised price discrimination against the Baltic states, especially before 2008, but perceptions of unfair pricing remain very strong among Baltic elites.

By September 2012, the Baltic states' complaints seemed to have gained traction within the context of the EU. According to Lithuania's Prime Minister Andrius Kubilius, the government approached the European Commission's Directorate General for Competition in the spring of 2011 regarding Gazprom's practices. ${ }^{31}$ On September 4, 2012 the Commission launched a formal antitrust investigation against Gazprom. Antoine Colombani, spokesman for EU Competition Commissioner Joaquín Almunia, stated that the inquiry had been launched following an official complaint by Lithuania but reflects the confirmed signals given by "market players" in general. Eight countries - Poland, The Czech Republic, Slovakia, Hungary, Bulgaria, Estonia, Latvia and Lithuania - are the markets where Gazprom's actions prompted the Commission to open an antitrust inquiry against Gazprom. ${ }^{32}$ The Commission is investigating three suspected anti-competitive practices in Central and Eastern Europe including:

1) hindering the free flow of gas from one country to another;

2) preventing diversification of supply of gas; and

3) imposing unfair pricing through its oil-based gas pricing mechanisms. ${ }^{33}$

In the Baltic states, the first practice is less relevant because they are not transit states and do not have the infrastructure to receive or deliver gas outside of their region or Russia. The second condition most likely refers to Gazprom's efforts to deny third parties access to its pipelines ${ }^{34}$ but in the Baltics could also refer to attempts to block construction of gas diversification projects such as liquefied natural gas (LNG) terminals and alternative

\footnotetext{
30 Information from official Gazprom website as of December 2011, www.gazpromexport.com, $<$ http://www.europeanenergyreview.eu/data/docs/Viewpoints/081122\%20Gas\%20Price\%20Factsheet $\% 20 \mathrm{G}$ ENERIC\%20final.pdf $>$. For an explanation of how the European netback market pricing mechanism operates see Stern 2012b, especially pp.54-59.

${ }^{31}$ Gotev 2012.

32 Gotev 2012.

33 "Antitrust: Commission opens proceedings against Gazprom".

${ }^{34}$ Riley 2012.
} 
pipelines. The third area of inquiry is particularly relevant in the Baltic states where gas pricing is allegedly abusive and is certainly indexed to the price of oil.

The investigation is already perceived as more than just a bureaucratic inquiry, because the Commission does not launch investigations unless it has obtained considerable evidence. The evidence probably comes from raids on Gazprom's offices in the Czech Republic and Germany in September 2011 and extensive market monitoring. The Directorate General for Competition has not lost an abuse-of-dominance case before the European Court of Justice since the EU's antitrust rules came into being in $1958 .{ }^{35}$ Nevertheless, the outcome and the effects of this investigation are uncertain.

The investigation can be viewed as the Commission putting pressure on Gazprom to alter its pricing model from oil-linked to hub-based prices - a change Gazprom has strongly resisted. While in the past 3-4 years some Western European energy companies have managed to renegotiate contracts with Gazprom to get price discounts and introduce partial spot price indexation, the markets of CEE have been less successful in gaining concessions from Gazprom. This investigation is likely to give the CEE states more leverage but the transfer to spot-dominated pricing would take decades and may in the end result in a hybrid (spot/indexation) pricing system. ${ }^{36}$ If the Commission's investigation fails to deliver results, the Baltic states will be further disadvantaged as Europe moves towards hub-based prices because they are not connected to European gas markets and are not close to any hubs that would allow them access to gas at competitive market prices. ${ }^{37}$

\section{The Third EU Directive and Unbundling of Gas Networks}

By the end of 2011, gas prices became part of the broader drawn-out conflict between Gazprom and Lithuania over Vilnius' plans to implement the EU⿴囗十 Third European Energy Package. The 'Third Package' calls for "unbundling" which means separation of transmission and distribution of gas from supply in order to encourage competition. In the Baltic states it means separating Gazprom's ownership of gas supply operations to consumers from ownership of the gas transmission and distribution pipelines. Of the three unbundling options proposed by the European Commission - ownership unbundling (OU), independent system operator (ISO) and independent transmission operator (ITO) Lithuania selected the most stringent Commission-preferred option of OU, in which both

\footnotetext{
${ }^{35}$ Riley 2012.

${ }^{36}$ Danila Bochkarev, Senior Fellow at the EastWest Institute, cited in Gotev 2012.

${ }^{37}$ For a discussion of hub-based pricing see Stern and Rogers 2012, pp.145-177.
} 
the management and the assets of gas networks are sold by the vertically integrated companies, to other companies which have no interests in gas production or supply. ${ }^{38} \mathrm{~A}$ 2010 Lithuanian law proposed that the transmission business of Lietuvos Dujos (37\% owned by Gazprom, $39 \%$ by Germany's E.ON, $18 \%$ by the Lithuanian state and $6 \%$ by private investors) would be separated from the distribution business. The ownership of the transmission networks would be shifted to the Lithuanian state. Gazprom, Lietuvos Dujos, and even Vladimir Putin tried to change Vilnius' stance towards unbundling by indirect threats of higher gas prices, international arbitration and media assaults.

In March 2011, the Lithuanian state started legal proceedings against Gazprom in Lithuanian courts arguing that Gazprom had reneged on the privatization provisions of national gas company Lietuvos Dujos by discriminating against the Lithuanian gas market and by exerting economic and political pressure on the Lithuanian state. ${ }^{39}$ These claims most likely resulted from statements in 2010 and 2011 by Gazprom and Lietuvos Dujos, suggesting that Lithuania was charged higher gas prices than Latvia and Estonia because Vilnius sought to implement the EU's Third Directive, while Tallinn and Riga had opted for less stringent 'unbundling' policies and to delay them until 2014. During the legal proceedings the Lithuanian courts ousted the chairman of the board and several board members from Lietuvos Dujos because they allegedly worked solely for Gazprom rather than Lietuvos Dujos. ${ }^{40}$ In June 2011, Gazprom filed an action with Stockholm's Arbitration Institute asking it to prohibit Lithuania's courts from pursuing the case. At the end of July 2012 the arbitral tribunal came to a decision that was claimed as a victory by both sides. In favour of Gazprom, the court ruled that the Shareholder Agreement was the sole document that determines gas prices and that the issue of gas discrimination could not be brought to Lithuanian courts. In favour of Lithuania, the court ruled that Gazprom could not claim damages from Lithuania and that Vilnius could pursue an investigation into the practises of Lietuvos Dujos in the Lithuanian courts and the issue of price discrimination could be addressed in international arbitration. ${ }^{41}$ On October 3, 2012, seemingly in response to Stockholm's decision and the EC's investigation into Gazprom's practises, the

\footnotetext{
${ }^{38} \mathrm{OU}$ is ownership unbundling, ISO is independent system operator, and ITO is independent transmission operator.

${ }^{39}$ Press release, The Energy Ministry of the Republic of Lithuania, 3 March 2011.

${ }^{40}$ Press release, The Energy Ministry of the Republic of Lithuania, 17 March 2011.

41 "Stokholmo arbitražas atmetė 'Gazprom' pretenzijas Lietuvai dèl 'Lietuvos dujų' veiklos tyrimo"; "International arbitration settles Gazprom's claims against Lithuanian Ministry of Energy".
} 
Lithuanian government filed a claim against Gazprom for $\$ 1.9$ billion, which is the amount Lithuania allegedly overpaid for gas. ${ }^{42}$

The 'unbundling' conflict also continues. In March 2012 Gazprom took Lithuania to international arbitration at the UN, according to UNCITRAL rules, over Vilnius' plans to break up Lietuvos Dujos, and disagreements over heat tariffs in Kaunas where Gazprom owns a thermal power plant. While a partial agreement that unbundling will proceed was reached between Lithuania and Gazprom in May 2012, Gazprom reserved its arbitration rights.

In contrast to Lithuania, both Estonia and Latvia initially sought an exemption from the new EU gas directive until 2014, which was available to them as EU members whose energy infrastructure is not connected to the rest of the EU. They have both opted for the ITO option, which allows energy companies to retain ownership of their transmission networks but makes the transmission subsidiaries legally independent stock companies operating under their own brand name, different management and strict regulatory oversight. This was the least stringent and the most favourable option for Gazprom. Latvia's Ministry of Economics argued that in the light of the small size and idiosyncratic features of the country's energy market, ownership unbundling would result in a fragmentation that would not be in its interests. In fact Latvia was among the EU states that initially called for more lenient unbundling options. Insiders suggest that Latvijas Gaze together with the largest Latvian consumer of Russian gas, the national electricity producer Latvenergo played a significant role in the government's energy policy and position on unbundling. The latter was also greatly influenced by the fact that the government has an agreement with Latvijas Gaze giving the company exclusive rights to ensure gas supply and distribution until 2017. Unbundling could result in considerable costs for the Latvian government for breaking the terms of this agreement.

By 2012 Estonia's policies changed course towards OU rather than the ITO model. The Estonian government passed legislation in June 2012 to force the national gas company Eesti Gaas (Gaprom owns 37\%, E.ON Ruhrgas 34\%) to sell its pipeline unit by 2015. E.ON Ruhrgas and Fortum hinted to take legal action with Gazprom likely to follow suit. ${ }^{43}$

\footnotetext{
42 "Lithuania hits Gazprom with \$1.9 billion claim", www.theguardian.co.uk, 3 October 2012.

43 "Eesti Gaas Shareholders Imply Possibility of Legal Action", ERR - Estonian Public Broadcasting, 31 May 2012.
} 


\section{Gas Diversification}

Despite the fact that the Baltic policy elites recognized the vulnerability of their energy sector from the start of independence, there has been surprisingly little progress on the part of governments to diversify gas sources or infrastructure. Baltic success stories regarding energy diversification are limited to two projects but neither is in the gas sector. First, in December 2006, Estonia completed Estlink, an electricity cable that links Estonia and Finland. Second, Lithuania implemented an oil diversification project by opening the Būtingè oil terminal in 1999 - a terminal which can import non-Russian sources of crude oil. Energy security came to the forefront of Baltic agendas only in the 2000s, primarily as a way to pressure the EU to provide assistance for the Baltic energy sector rather than as part of domestic programmes aimed at altering the national energy predicament. Thus, despite the intensive EU and NATO-oriented discourses calling for elimination of the last vestiges of dependence on Russia, little action was taken by the Baltic governments until the late 2000s when lobbying for EU assistance intensified.

By 2009 the European Commission together with Member States of the Baltic Sea Region (Finland, Estonia, Latvia, Lithuania, Poland, Germany, Denmark, Sweden and Norway as an observer) delivered the Baltic Energy Market Interconnection Plan (BEMIP) aimed at energy interconnection of the Baltic region. ${ }^{44}$ BEMIP includes plans for electricity links such as Nordbalt (Sweden-Lithuania-Latvia) and Estlink2 (Finland-Estonia), a land-based LNG terminal, a floating LNG terminal and (as of 2011) support for studies on: connecting the Baltic states to the EU electricity market, a gas pipeline link with Poland, and LNG storage in Lithuania among others. There are other ambitious energy projects such as a new nuclear power plant and a gas storage facility in Lithuania. However, despite being on the agenda since the mid 1990s, to date none of these projects have moved to the construction stage. The LNG terminal and Nordbalt have been delayed because of the inability of the participating states to agree on the location of the terminal or the termination point of the electricity cable from Sweden, with both Lithuania and Latvia insisting that the project be on their territory. The gas connection between Poland and Latvia has been in discussion since the 1990s but has not attracted serious interest from the Polish side.

In addition to lack of agreement, there are three main reasons why diversification of sources or infrastructure has not been achieved in the Baltic states to date: costs, institutional weakness, and vested interests in the gas sector. The high costs of building

\footnotetext{
44 "Baltic Energy Market Interconnection Plan". Progress Report June 2011, European Commission.
} 
alternative energy supply infrastructure and the lack of political will to bear these costs are arguably the main barriers to action. Existing Soviet-era pipelines and the relative stability of gas deliveries (particularly at below market prices in the 1990s) made the Baltic governments complacent about seeking alternatives. Even if the Baltic states had been prepared to pay market prices for gas, accessing alternative gas supplies without new infrastructure would have been impossible. According to the calculations of the Lithuanian Ministry of Foreign Affairs, making energy security a reality in Lithuania would cost EUR27.5 billion or the equivalent of four annual state budgets. ${ }^{45}$ Since the three Baltic states share similar infrastructure, resources, and geography, Lithuania's calculations can be taken as an indicator for the other two Baltic states as well. According to the same calculations, alternative gas infrastructure alone would cost Lithuania EUR800 million. ${ }^{46}$ Building a land-based LNG terminal in any of the Baltic states could cost at the very minimum EUR400 million according to some government calculations but more likely close to EUR1 billion. While the Baltic states have complained that they were exploited by the Russians, considering the high costs of alternatives and the fact that the Baltic governments failed to implement diversification for more than twenty years, one can conclude that diversification options were uneconomic. Looking forward, diversification will remain difficult to justify economically without EU or Baltic government subsidies.

Notwithstanding the high costs, the second reason why diversification was not implemented was the institutional weakness of Baltic governments and the bureaucracies which would need to implement costly and complex gas diversification projects. Immature democracies suffer weakness such as fragile coalition governments, short-lived governments, ministers with even shorter tenures, and populist tendencies amongst political parties. These domestic political conditions together with the high costs of diversification have created impotence and reduced the political will of Baltic governments to alter their gas predicament. On the other hand, the lack of action in the face of energy insecurity and complaints about Russia's energy strong-arm tactics also shows that the Baltic governments opted for other economic and political priorities instead of diversification.

A third reason for Baltic governments' failure to diversify is related to the preferences of local stakeholders who profit from the extant Russian-Baltic gas relationship and who have kept - via their influence over politics and the media - the gas sector off the agenda.

\footnotetext{
45 According to Vytautas Naudužas, representative of the Economic Security Department of Lithuanian Ministry of Foreign Affairs. cited in "Energetinio saugumo pavertimas realybe atsietų 27,5 mlrd. eurų URM".

${ }^{46}$ Vytautas Naudužas cited in "Energetinio saugumo pavertimas realybe atsietų 27,5 mlrd. eurų - URM".
} 
Influence on political parties was exercised through unofficial campaign and party contributions. Particularly in Lithuania and Latvia, gas distributors and gas companies played a significant role in domestic politics and had notable influence over policy making. The influence over media was exercised either through direct ownership of newspapers, television, and radio stations, ${ }^{47}$ or through financial contributions to key media outlets. ${ }^{48}$ The inactivity of governments in terms of resource and source diversification was most evident in Latvia, where the authorities hampered the development of renewable energy resources and energy efficiency, decentralization of energy production, and regional cooperation. $^{49}$

Despite these hindrances to diversification, by 2011, the idea of building a land-based LNG terminal gained traction in all three Baltic states, particularly after the EC expressed its support for such a project, but without earmarking structural funds for its implementation. Currently there are plans for a floating low-cost terminal in Lithuania and a land-based terminal in one of the Baltic states which would meet the needs of the whole region. Since 2009, Lithuania has been discussing the idea of building a floating LNG terminal which would be quicker, easier and less costly to set up - currently estimated at EUR200 million. ${ }^{50}$ After much delay, due to a political stalemate and unwillingness in 2009 to fund the feasibility study, in December 2011 the Lithuanian government approved the development plans for a floating terminal in Klaipeda. ${ }^{51}$ The project will be carried out by the government-controlled oil terminal operator Klaipedos Nafta. A 20\% stake may be offered to outside investors, with Norwegian Hoegh, the LNG vessel provider, and American Cheniere Energy, a possible LNG provider. In June 2012, the Lithuanian parliament approved the plans for the floating LNG terminal, which according to government is scheduled to be completed by the end of $2014 .^{52}$ However, long delays are very likely. First, the project was supported by the outgoing Lithuanian government led by the conservative Homeland Union party in power from 2008-2012. Considering that the

\footnotetext{
${ }^{47}$ For instance, Achema, the largest gas consumer in Lithuania owns the BTV television station and the Radiocentras and Lietuvos Radijas radio stations.

${ }^{48}$ In 2007, the Lithuanian National Security and Defence Committee revealed that gas distributor Dujotekana paid the main Lithuanian newspapers Lietuvos Rytas and Respublika not to reveal links between the company and politicians as well as the Lithuanian Internal Security Department (government security and intelligence institution). Pečeliūnaitè 2007.

${ }^{49}$ Sprūds 2009, p.235.

${ }^{50}$ Kitąmet bus statomas suskystintas dujų terminalas.

${ }^{51}$ Interview with EXMAR, Vilnius, Lithuania, February 2010.

52 "Seimas pritare suskystintų gamtinių dujų terminalo statybai".
} 
upcoming Lithuanian parliamentary elections on 14 October 2012 are likely to bring to power a different coalition of political forces, it is questionable that the new government will implement these plans, which currently only exist on paper. Second, groups close to Gazprom as well as alternative projects in Latvia and Estonia will continue to lobby against such a project.

Latvia and Estonia have emerged as the most likely contenders for the stationary, ECfunded LNG terminal which would meet the gas needs of the whole region. If planned in Latvia, the project would be led by the Latvian state power company Latvenergo and built in the port of Riga. Latvia's primary advantage is its gas storage facilities and the fact that gas pipelines connect Latvia to both Estonia and Lithuania. However, in June 2012 an independent study led by the European Commission seemingly concluded that Estonia would be the best location for a regional terminal only if Finland joined the project. ${ }^{53}$ Finland has, however, not expressed interest in a regional LNG terminal and would prefer to have its own facility.

In Estonia, the state companies Elering (the electricity grid operator) and the Tallinn port operator, would be the likely players involved in building an LNG terminal. ${ }^{54}$ It is unlikely that the EU will fund the project unless all involved states will agree to a joint terminal. However, the three states and Finland have trouble trusting each other and finding political cooperation over gas security, with each wanting to have its own LNG terminal. Nonetheless, a recent study has demonstrated that an LNG terminal with security, rather than commercial considerations, as its priority would still make economic sense for all three Baltic states, and especially Lithuania due to its high cost of gas storage. ${ }^{55}$

Because of the political instability of Latvia in the late 2000s and the prohibitive costs and disagreements of building a regional land-based terminal, it is most feasible that floating LNG in Lithuania will be the first, and most likely only, project to be implemented in the near term. The completion of such a floating terminal would significantly alter the region's gas security, especially if the terminal remains in the ownership of the state or Western investors. The possibility of having alternative sources of gas could strengthen the Baltic bargaining position vis-à-vis Gazprom regarding gas prices and reduce the likelihood that Russia would use a gas cut off as a political weapon. Lithuanian preliminary estimates suggest that a floating LNG terminal in Klaipeda working at full capacity would be able to

\footnotetext{
53 "MP claims EC prefers Estonia as host to LNG terminal".

54 "EK tyrimas: SGD terminalas galetu buti statomas Estijoje".

${ }^{55}$ Noel, Findlater, and Chyong, 2012, p.20-33.
} 
fully meet Lithuania's gas needs and reduce gas prices for end consumers by $30 \%{ }^{56}$ However, with the fluctuation of LNG prices and the fact that LNG would have to be shipped from distant sources (for instance, in the Middle East, north or sub-Saharan Africa and North America), it is highly uncertain if an LNG terminal would actually reduce the price of gas to Lithuanian consumers. The main benefit would be improving gas security.

\section{Domestic Actors in the Baltic Gas Sector}

Since the energy sector has been perceived as a domain for energy practitioners and because there was little public interest in or scrutiny of the sector until the mid 2000s, policy has been dominated by large energy companies and vested political interests. ${ }^{57}$ The main non-governmental actors directly and indirectly influencing national gas policies towards Russia, were major gas distributors and corporate consumers. These companies often lobbied domestically in favour of Russian gas interests and against foreign investors and/or investment into alternative sources of energy such as wind or geothermal energy. Consequently, when Gazprom made major investments in the Baltic gas sector, local gas interests with ties to Gazprom became further entrenched in the domestic energy sector and its politics.

Local gas interests were more powerful than oil interests in their ability to influence policy making in the Baltic states, and the operations of gas companies differed from oil companies. Companies profiting from gas transit or distribution were primarily local companies or local enterprises that drew on Russian investment. Entities such as Dujotekana, Vikonda, Itera and others could theoretically use their influence less transparently and more directly over government. On the other hand, oil companies operating in the Baltic market were most often international or public companies bound by transparency and standardized rules of practice. Baltic domestic gas actors can be broken down into three categories - national gas companies, gas distributors, and gas consuming enterprises.

\section{National Gas Companies}

The three national gas companies, Estonian Eesti Gaas, Latvian Latvijas Gāze, and Lithuanian Lietuvos Dujos serve as distributors which purchase gas from Gazprom and deliver gas to households and businesses. Only Lietuvos Dujos remains partially owned by the Lithuanian state whilst Eesti Gaas and Latvijas Gāze are fully privatized. The

\footnotetext{
56 "Kitąmet bus statomas suskystintas dujų terminalas".

${ }^{57}$ Sprūds 2009, p.238.
} 
ownership structure of the three companies is similar. In each Baltic gas company, Gazprom owns significant shareholdings, which it acquired through incremental purchases. Itera, an international gas distributing company, whose ownership structure is not transparent but is generally believed to be a Russian company which was previously close to Gazprom, also owns shares in both Eesti Gaas and Latvijas Gāze.

Table 4: Gazprom shareholdings in Baltic national gas companies

\begin{tabular}{|c|c|c|c|}
\hline Country and Firm & $\begin{array}{l}\text { Ownership of firm } \\
\text { by Russian } \\
\text { companies (rounded } \\
\text { to nearest } \% \text { ) }\end{array}$ & $\begin{array}{l}\text { Ownership of } \\
\text { firm (rounded to } \\
\text { the nearest \%) }\end{array}$ & Main activity \\
\hline $\begin{array}{l}\text { Estonia } \\
\text { Eesti Gaas }\end{array}$ & $47 \%$ (Gazprom + Itera) & $\begin{array}{l}37 \% \text { Gazprom } \\
34 \% \text { E.ON Ruhrgas } \\
18 \% \text { Fortum Oil and } \\
\text { Gas } \\
10 \% \text { Itera Latvija } \\
2 \% \text { Private investors }\end{array}$ & $\begin{array}{l}\text { Import, transmission } \\
\text { (including ownership } \\
\text { of pipelines), and sales } \\
\text { of natural gas }\end{array}$ \\
\hline $\begin{array}{l}\text { Latvia } \\
\text { Latvijas Gāze }\end{array}$ & $50 \%$ (Gazprom + Itera) & $\begin{array}{l}47 \% \text { E.ON Ruhrgas } \\
34 \% \text { Gazprom } \\
16 \% \text { Itera Latvija } \\
3 \% \text { Private investors }\end{array}$ & $\begin{array}{l}\text { Import, transmission, } \\
\text { storage and sales of } \\
\text { natural gas }\end{array}$ \\
\hline $\begin{array}{l}\text { Lithuania } \\
\text { Lietuvos Dujos }\end{array}$ & 37\% (Gazprom) & $\begin{array}{l}39 \% \text { E.ON Ruhrgas } \\
37 \% \text { Gazprom } \\
18 \% \text { Lithuanian state } \\
6 \% \text { Private investors }\end{array}$ & $\begin{array}{l}\text { Import, transmission, } \\
\text { distribution, and sales } \\
\text { of natural gas }\end{array}$ \\
\hline
\end{tabular}

Source: Eesti Gaas, Latvijas Gāze, and Lietuvos Dujos websites as of September 2012.

The other main investor in the Baltic gas companies is the German company E.ON Ruhrgas, which has more shares than Gazprom in Latvijas Gāze and Lietuvos Dujos. Even though E.ON Ruhrgas partnered with Gazprom in the Baltic states and is the only foreign investor in Gazprom - owning $6.4 \%$ of its shares until 2011 - it had a complex relationship with Gazprom and Itera when it came to Latvijas Gāze. There have been tensions between E.ON Ruhrgas, Latvijas Gāze and Itera-Latvija regarding management of 
the company since 2005, and E.ON Ruhrgas has threatened to take legal action. ${ }^{58}$ The Eesti Gaas case is unique because outside the three common investors - E.ON Ruhrgas, Gazprom and Itera - there is a fourth investor, the Finnish public energy company Fortum.

The leadership and boards of the companies reflect the largest shareholders. In Lietuvos Dujos, the general director of the board is a Lithuanian with a Russian and a German in the executive directorship. The board of directors is composed of board members from Gazprom and E.ON Ruhrgas. This reflects the pervasive influence of Gazprom and E.ON Ruhrgas after 2004. The Lithuanian general director of the company recognizes that Gazprom's acquisition was highly controversial and suggests that the company has tried to maintain a 'Lithuanian face.' In Latvijas Gāze, the executive board is composed of a mix of Latvians and Russians, whilst the supervisory board is composed of Gazprom, E.ON Ruhrgas, and Itera board members reflecting the ownership structure of the company. ${ }^{59}$ In Estonia, the situation is slightly different, demonstrating less influence by the shareholders on the day to day operations of the company. Initially there were representatives from Gazprom and E.ON Ruhrgas in the management of Eesti Gaas - as is the case with Latvijas Gāze and Lietuvos Dujos. Since 1997, Eesti Gaas has been run by only local managers. Nevertheless, as would be expected of shareholders, Gazprom is able to exert influence on the board of directors. ${ }^{60}$

Because Gazprom is a major investor in all three national companies, it can be argued that the three enterprises represent to some extent Gazprom's interests in each of the gas markets of the Baltic states. Gazprom's significant share ownership means that national governments are constrained in their ability to implement policy that might contradict the interests of Gazprom. In the case of Lithuania, for example, the government share of Lietuvos Dujos is less than that of Gazprom. When it comes to negotiations with Russia it makes it impossible for the national gas company to raise transit tariffs to Kaliningrad, which Gazprom would oppose. ${ }^{61}$ However, under the EU's Third Package, it will be the regulatory authority, not the company, which will decide on tariffs. Furthermore, as strategic national companies, the three can effectively lobby the government not only in energy policy but also, potentially, with regard to foreign policy towards Russia.

\footnotetext{
58 "Transparency in Russia and Eurasia and Energy Security in Europe".

${ }^{59}$ Information from Lietuvos Dujos, Latvijas Gaze, and Eesti Gaas websites as of August 2012.

${ }^{60}$ Kilvits, Purju, and Pädam 2005, p.67.

${ }^{61}$ Janeliūnas 2009, p.199.
} 
In Latvia, this is evident in the activities of Latvijas Gāze and the electricity monopoly Latvenergo which, in the 2000s, assumed centre stage in energy decision-making through their political connections. ${ }^{62}$ Though it is not unusual for a gas company to lobby for gas, Latvijas Gāze, has openly lobbied against energy diversification. As the company's CEO Adrians Dāvis stated at the Latvian National Committee of the World Energy Council in December 2008, ?Latvian energy priority until 2020 must be gas. Renewable energy resources must be put aside...[the notion of a] Coal power plant is an absurd idea. [? ${ }^{63} \mathrm{In}$ comparison Eesti Gaas has remained the least politicized Baltic national gas company. However, there has been a limit to all three companies' ability to act as advocates of Gazprom interests in that they are public companies and their operations are governed by standards of transparency.

\section{Gas Distributors}

A second group of actors in the domestic gas market which often are less scrutinized and whose activities are even less transparent than the national gas companies are gas distribution companies, such as Itera (operating in Latvia, Lithuania), Dujotekana (Lithuania), Stella Vitae ${ }^{64}$ (Lithuania), and Vikonda (Lithuania). All these distributors have an opaque ownership structure and are widely believed, though not proven, to have or have had strong ties to Gazprom. They facilitate the participation of Gazprom in the final gas market and sell gas to customers. Assuming the alleged partial ownership of these distribution companies or alleged influence over their owners is true, Gazprom's share in Baltic states' final gas markets is the largest of any of its holdings within the EU. ${ }^{65}$ That said, these distribution companies, run by former local Communist Party bosses, are not unique to the Baltic states and are also prevalent in Central and Eastern Europe and the CIS. $^{66}$

Itera stands apart from the other smaller Baltic distributors because it is a sizable international organization consisting of more than 120 companies and subsidiaries

\footnotetext{
${ }^{62}$ Sprūds 2009, p.239.

${ }^{63}$ Sprūds 2009, p.240.

${ }^{64}$ Stella Vitae is a Russian-Lithuanian joint company reportedly owned by Gazprom $(30 \%)$ and a Russian company, Auri, which was linked with the former head of Gazprom, Rem Viachirev (35\%). As with Dujotekana, Stella Vitae lost its prominence as a gas trader when Gazprom acquired shares in Lietuvos Dujos in 2004. "Stella Vitae žada atnaujinti dujų tiekimą".

${ }^{65}$ Łoskot-Strachota and Pełczyńska-Nałęcz 2008.

${ }^{66}$ Vilemas 2002, p.50. "Transparency in Russia and Eurasia and Energy Security in Europe".
} 
headquartered in Moscow. After entering the gas production business in 1998, it became one of the largest gas producers in Russia by $2000 .^{67}$ There are various opinions regarding Itera's ownership structure. Because Itera received gas assets for virtually no payment from Gazprom some have argued that Itera's ownership structure throughout the 1990s was closely linked to Gazprom's founder CEO Rem Vyakhirev. ${ }^{68}$ However, a Russian investigation found no wrongdoing and allegations of fraudulent gas acquisitions or Gazprom's ownership have not been substantiated. ${ }^{69}$

In the Baltic states, Itera operates both as a gas distributor and as an investor in the national gas companies. In Estonia and Latvia, its subsidiary Itera Latvija owns shares in both Eesti Gaas and Latvijas Gāze. In Latvia, Itera Latvija has supplied gas since 1997, in its peak providing one fifth of the national demand for gas in 2003. In Lithuania, Itera has been a gas distributor since 1996 but not a major player in the sector, ${ }^{70}$ whilst in Estonia Itera does not have distribution operations and is only a shareholder in the national gas company. The operations of Itera's subsidiaries in the Baltics have raised concerns amongst analysts and policy makers. Though allegations have not been substantiated, Itera has been described as 'another example of Gazprom's establishment of fictional competitors,' which 'allowed Gazprom to siphon off earnings to company managers and sympathetic Russian officials' in the 1990s. Further suspicions are aroused by the fact that Itera Latvija is run by a Russian with close ties to the Kremlin. ${ }^{71}$ However, after Alexey Miller replaced Vyakhirev in 2001, Itera and Gazprom increasingly grew apart and were generally not considered close allies by $2012 .^{72}$

Dujotekana, Stella Vitae, and Vikonda all operate in Lithuania and unlike Itera are smaller and more obviously local operations. These gas distributors are privately owned with close links to Gazprom. There are widely believed suspicions that they operate by receiving gas at lower prices than Gazprom charges Lietuvos Dujos. According to these allegations, receiving gas at a discount enables these companies to make sizable profits and compete

\footnotetext{
${ }^{67}$ LeBras 2000.

${ }^{68}$ Silverstein 2006. McGregor 2002.

${ }^{69}$ For details see Stern 2005, pp. 22-25

${ }^{70}$ Based on information provided by the $<$ www.iteragroup.com $>$ website.

71 Since 1996 Itera Latvija has been headed by Juris Savickis, a former KGB officer with no previous experience in the energy sector. Smith 2004, p.38. Vilemas 2002, p.51; "Transparency in Russia and Eurasia and Energy Security in Europe".

72 Since 2002, Itera has lost much of its support in the Kremlin, and Smith argues that Gazprom has created alternative partner companies abroad. See Smith 2004, p.39.
} 
with national gas companies. For instance, in 2000 , only $25 \%$ of gas supplied by Gazprom to Lithuania was allocated to Lietuvos Dujos, whilst Dujotekana delivered $30 \%$ of the Gazprom gas consumed in Lithuania. The reason why there are smaller and independent Lithuanian gas distributors, but no such operations in Latvia and Estonia, has to do with the way Gazprom has entered and acted in the Lithuanian market. It has been argued that Gazprom supported the creation of Dujotekana, Stella Vitae, and Vikonda in order to have influence over the gas distribution market in Lithuania and compete with Lietuvos Dujos, as it was unable to acquire shares in Lietuvos Dujos until 2004. By way of contrast, there was no need for the creation of Gazprom-friendly local distributors in Estonia and Latvia because Gazprom gained control over gas distribution in these markets through the acquisition of shares in Eesti Gaas and Latvijas Gāze in the 1990s. Furthermore, after 2004, when Gazprom acquired shares in Lietuvos Dujos, the local distributors such as Dujotekana, Stella Vitae, and Vikonda lost prominence.

Other allegations against these companies include suspicions that they channel financial support to local political parties. ${ }^{73}$ Dujotekana is registered in Lithuania and has been operating since 2001, primarily as an intermediary in Russian gas trade. In 2008, it was the largest natural gas importer in Lithuania after Lietuvos Dujos and Achema though it has lost its leading position since. In addition to gas sales to primarily electricity producers, Dujotekana produces electricity and heat and sells electric energy. It has been alleged (but not proven) by the Lithuanian National Security Department that the company was created with the approval of then Prime Minister Vladimir Putin and the involvement of the Russian secret services. ${ }^{74}$ It has also been speculated that Dujotekana was intended to facilitate Gazprom's takeover of Lietuvos Dujos. ${ }^{75}$ This seems to be supported by the fact that in the years following Gazprom's acquisition of a large stakeholding in Lietuvos Dujos in 2004, Dujotekana's position as a strategic partner of Gazprom weakened. ${ }^{76}$ This could be due to two factors. First, Gazprom established its own footprint in the Lithuanian gas market through acquiring shares in Lietuvos Dujos and Stella Vitae. Since Gazprom did not own any shares of Dujotekana, it became, as it were, a competitor to Gazprom's other operations. Second, gas industry insiders speculate that Dujotekana, despite being very influential politically in the early 2000s, failed to deliver the degree of political leverage expected by Gazprom in the Lithuanian context and thus lost favour with the

\footnotetext{
73 "Dujotekanos’ čiuptuvuose - korumpuotos Lietuvos valdžios piramidè".

${ }^{74}$ Tvaskienè 2009.

${ }^{75}$ Łoskot-Strachota and Pełczyńska-Nałęcz 2008.

76 "NSGK išslaptino pareigūnų liudijimus (dokumentai)".
} 
Russian company. ${ }^{77}$

Dujotekana's most visible shareholder, Lithuanian businessman Rimantas Stonys (34\% of shares), has been under scrutiny as a highly influential behind-the-scenes player in

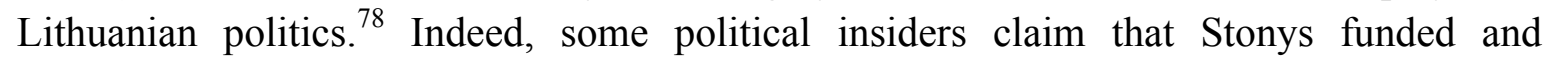
significantly influenced the Social Democrat government of Lithuania (2006-2008). Head of the conservative Homeland Union party and Prime Minister since 2009 Andrius Kubilius, together with Homeland Union member and Minister of Defense since 2009 Rasa Juknevičienė, have publicly suggested that Prime Minister Gediminas Kirkilas gained his position thanks to Stonys. ${ }^{79}$ Stonys also reportedly influenced the appointment of the cabinet of ministers ${ }^{80}$ and the affairs of the government. Stonys allegedly worked closely with Albinas Januška, deemed the 'grey cardinal' of Lithuania who served as Vice Minister of Foreign Affairs and later as advisor to Kirkilas. ${ }^{81}$

Other shareholders of Dujotekana include the less visible, alleged former KGB officer Petras Vojeika (40\% of shares) and former member of Parliament, Russian-born Vladimiras Orechovas (6.8\% of shares) from the Labour Party. Other members of New Union Social Liberals and Labour parties, whom Dujotekana allegedly supported financially, also count amongst the smaller shareholders. ${ }^{82}$ Both of these political parties are from the left of the political spectrum and typically lobby in favour of cooperative relations with Russia. It is also alleged that Dujotekana made financial contributions to all the major Lithuanian political parties including the Social Liberals, the Social Democrats, and the Homeland Union, particularly before parliamentary elections in $2004{ }^{83}$

If Gazprom did in fact have a hand in creating these distribution companies which, because of their relationship with Gazprom have registered sizable profits, it is arguable that these local companies were obedient to the mother company in order to ensure their financial success. ${ }^{84}$ It is possible to extend this argument further and say that these gas distributors

\footnotetext{
${ }^{77}$ Interview with Baltic and CIS energy industry insider, London, March 2008.

78 Tvaskienė 2009. "Dujotekanos' čiuptuvuose - korumpuotos Lietuvos valdžios piramidė".

${ }^{79}$ Čyvas 2008; Damulytė 2008.

${ }^{80}$ Interview with an insider from the Lithuanian Homeland Union Party, Vilnius, March 2008.

81 "Pilkasis kardinolas Albinas Januška grịžta".

${ }^{82}$ Tvaskienė 2009. 'Dujotekanos' čiuptuvuose - korumpuotos Lietuvos valdžios piramidè'. Šindeikis 2006.

${ }^{83}$ Janeliūnas 2009, p.212.

${ }^{84}$ Vilemas 2002, p.51.
} 
served as a means for the Kremlin to maintain political and economic influence in the region. Their loyalty was tested, and competition was maintained between the distributor companies as demonstrated by the fact that different companies were given different gas quotas in different years. For instance, in the late 1990s, Stella Vitae was the primary gas distributor in Lithuania; in 2000 it was Itera Lietuva, and by 2002 Dujotekana became the leader in gas distribution, a position it lost after Gazprom acquired shares of Lietuvos Dujos. Whilst the players and their roles varied across the Baltic states and over time, there are widely believed allegations that in all three states gas distributors with opaque ownership served as Moscow's intermediaries in the final gas market, using their sizable profits for political influence.

\section{Gas Consuming Enterprises}

A third group of companies that were significant players in the Baltic gas sector was made up of local enterprises relying on Russian gas for operations. Unlike the Moscowsponsored gas distributors they work in more transparent ways but their influence on the gas sector and domestic politics is also notable. There are three key players in this category. They differ in ownership structure but all are dependent on Gazprom's provision of gas. The first is the Achema group which is owned by local Lithuanian businessmen. The second is Nitrofert, an Estonian company that was privatized by a Ukrainian businessman with alleged close ties to Gazprom. The third is the Latvian public company Latvenergo Group.

The Lithuanian Achema Group is the second largest privately owned business enterprise in Lithuania. It is one of the most significant enterprises in the Baltics, managing more than 50 business groups in 2008, achieving a turnover of EUR1,457 billion and a net profit of EUR135 million. Achema Group's homonymous chemical business Achema accounted for about a quarter of gas used in Lithuania 2010. Whilst it received gas at a discount until the late 2000s, since then all of its gas is purchased from Gazprom at similar prices to those charged to Lithuanian gas distributors. ${ }^{85}$

Achema Group is one of the most politically influential companies in Lithuania. The former CEO and primary shareholder of Achema Group was Lithuanian businessman and former Prime Minister Bronislovas Lubys until his death at the end of 2011. Since the 1990s, Achema Group and Lubys reportedly made political contributions to various politicians and political parties, including the two largest parties on both sides of the

\footnotetext{
${ }^{85}$ Interview with Achema management, Vilnius, Lithuania, December 2009.
} 
political spectrum - the Social Democrats and the Homeland Union. Heading the Lithuanian Federation of Industrialists, Lubys also actively lobbied the government for more cooperative relations with Russia arguing that it would benefit Lithuanian businesses. ${ }^{86}$ Lubys likewise lobbied for lower gas prices, drawing an explicit link between the poor relations between Vilnius and Moscow and the high gas prices Gazprom charged Lithuanian enterprises. $^{87}$

Meanwhile, in Estonia, the largest consumer of gas is Nitrofert, a producer of fertilizers. Nitrofert relies on Estonian oil shale and Russian natural gas, making it the second largest importer of gas in Estonia after Eesti Gaas. Nitrofert consumes about 25\% of the natural gas purchased by Estonia annually. Whilst Nitrofert may seem similar to Lithuania's Achema, it is not owned by local businessmen. Rather, it is owned by Ostchem Holding $\mathrm{AG}$, which is in turn owned by Group DF, an international private holding company of prominent Ukrainian businessman Dmitry Firtash. The companies belonging to Firtash are believed to have indirect links to Gazprom. However, unlike Achema in Lithuania, Estonia's Nitrofert does not have notable influence in domestic politics. ${ }^{88}$

The third company in the Baltics that is a major consumer of gas is a Latvian public energy company Latvenergo Group. Latvenergo's unique position in the Latvian economy, politics, and society is illustrated by the fact that despite efforts since the mid 1990s to privatize the company, it remains public. This is a function of political forces and a 2000 petition signed by $23 \%$ of Latvian citizens demanding a referendum against privatization. ${ }^{89}$ As a state-owned public company, Latvenergo differs from Achema, and Nitrofert. It is an energy utility whose core business is the generation and sale of electricity and thermal energy. Latvenergo is the largest consumer of Russian gas in Latvia, accounting for approximately half of the country's consumption. Similarly to Achema, the Latvenergo Group is influential both in domestic politics and in national energy policy. Latvian politicians have even suggested that the Ministry of Economy is led by Latvenergo rather than the appointed Minister. ${ }^{90}$ Since the Latvenergo Group relies exclusively on gas imported by Gazprom, its interests often coincide with other major Russian gas importers

\footnotetext{
${ }^{86}$ For his efforts to improve business relations between Lithuania and Russia, he was awarded the Peter the Great award in Moscow in 2003.

${ }^{87}$ Interviews with Lithuanian diplomats at the Lithuanian Foreign Ministry, Vilnius, Spring 2009.

${ }^{88}$ Interview with anonymous Baltic diplomat, Vilnius, 27 January 2010.

${ }^{89}$ Lill 2001; Updated by Ville Rämänen in October 2002.

${ }^{90}$ Viesturs Silenieks, the co-chair of Green party, cited in Sprūds 2009, p.239.
} 
such as Latvijas Gāze and Itera Latvija. ${ }^{91}$ With the growing electricity shortage (experienced in the other two Baltic states as well) Latvenergo has prioritized Russian gas as the major generating resource.

The different levels of involvement in local politics of Achema and Latvenergo on one hand, and Nitrofert on the other, highlight a major difference between the domestic business environment of Lithuania and Latvia versus Estonia. Estonia's legal framework created in the early 1990s enabled an environment where business remains separated from politics to a much greater extent than in Lithuania and Latvia. ${ }^{92}$ The difference in the ownership structure of Achema and Nitrofert is representative of the difference in private sector ownership across Lithuania and Estonia. Lithuania has a number of sizable and strategic companies owned by Lithuanians, albeit some with close links to Russian companies. By contrast, Estonia's liberal policies of the 1990s resulted in most Estonian enterprises being owned by foreign investors, either Western or Russian. In Latvia, whilst Latvenergo is a public company, the business community in general is dominated by either Latvian Russian speakers or by Russian investors. Ethnic Latvians until recently were significantly under-represented in the fields of strategic commerce and industry. This has given rise to the claim that Latvia is the most Russian-dominated economy and energy sector in the Baltic. Indeed, Russian gas interests are in fact highly entrenched in the Latvian political system. ${ }^{93}$ The specific domestic conditions of lack of transparency and accountability enabled companies such as Latvenergo, Latvijas Gāze, and Itera Latvija to acquire considerable influence not only in energy policy but also in foreign policy towards Russia. More broadly, the domestic actors in the Baltic gas sector that have been outlined in this section are all believed to have links with Gazprom and allegedly support Moscow's energy interests to which we now turn.

\section{Russian Gas Policies}

Russian energy politics and policies and their evolution could be described as basically displaying a three-pronged strategy since 2000. Arguably the first tenet of Moscow's new energy policy is that the Kremlin has not hesitated to use energy as a tool of the state's geopolitical influence especially in the former Soviet republics. The second aspect of Russia's energy policy was the re-orientation of energy transit to Europe away from old

\footnotetext{
${ }^{91}$ Sprūds 2009, p.240.

${ }^{92}$ Interview with anonymous Baltic diplomat, Vilnius, 27 January 2010.

${ }^{93}$ Interviews with Latvian decision makers and academics.
} 
routes via former Soviet and socialist European states, to new and more direct routes through Russian territory and ports. The third pillar focused on securing full control over the Russian energy sector and expansion into the energy sectors of neighbouring states, often through acquisition of downstream assets.

Moscow's pursuit of the first tenet, namely the use of energy policy for geopolitical leverage, appears at first glance to be less relevant to the Baltic gas sector. Despite the seemingly high levels of vulnerability of the Baltic gas sectors, ${ }^{94}$ Moscow did not at first implement gas interruptions and gas pipelines to the Baltic states continued to operate. However, successive gas interruptions to Ukraine (March 2005; March 2008; December 2008 ) and to Belarus in February 2004 sent shivers down the spine of Baltic policy elites.

The second and third tenet of Moscow's energy policy which evolved by the late 1990s relate to oil and gas export infrastructure, and centre on eliminating transit states in energy flows westward. By the 2000s Russia's position was that oil and gas would only be transited, transported or refined in Russian-owned infrastructure. Russian national oil and gas companies sought to acquire transit networks, transport infrastructure, refineries and storage in transit states such as the Baltics, Ukraine, Belarus, Moldova, Armenia and others. If countries agreed - like Belarus - to sell their networks to Russian companies then sometimes they received preferential treatment and prices. But not always, as in the cases of Moldova and Armenia. ${ }^{95}$ When countries refused to sell their transit infrastructure, Moscow sought to find another route - whatever the cost. The first manifestation of this policy was in the Baltic oil sector. When the Baltic states resisted selling to Russia its oil assets such as Latvian port facility Ventspils Nafta or Lithuanian oil refinery Mažeikiu Nafta, Russia closed down pipelines supplying these facilities and sought new routes. ${ }^{96}$ As a result Russia re-routed oil flows when it updated its energy export infrastructure through the completion of Baltic Pipeline System (BPS) in 2001 and the two Primorsk oil terminals in 2006 and 2008 and cut the Baltic states out of the oil transit business. Going forward, Russia aims to expand BPS to bypass Belarus and the Baltic states completely, and to nearly double the capacity of its northwestern ports of Ust-Luga, Primorsk, Vysotsk, Kaliningrad and Murmansk by 2015. The second manifestation of this policy was in the gas sector where projects such as Nord Stream and South Stream have been aimed at cutting countries such as Ukraine out of the gas transit business.

\footnotetext{
${ }^{94}$ Riley 2009.

${ }^{95}$ Particularly Moldova; in 2012 Armenia is paying relatively low prices but this was not always the case. See Henderson, Pirani, and Yafimava 2012.

${ }^{96}$ Grigas 2013.
} 
The Baltic states are not transit states for Russian gas to Western markets - only Lithuania is a transit state for Russian gas destined for Kaliningrad. Thus they have not been objects of Russian efforts to cut them out of gas transit but are also unlikely to ever become gas transit states. Russia's lack of interest in the proposed Lithuanian and Polish Amber pipeline to carry Russian gas westward through Lithuanian and Polish territories confirms this policy. ${ }^{97}$ In accordance with the third tenet of Russian policy, namely the commitment to securing control of infrastructure and downstream assets, Gazprom has made aggressive bids for Baltic national gas distributors as described in the case studies (see Appendix). Overall the last two tenets of Russia's energy policy may not be 'friendly' but they are primarily commercial rather than political. It is reasonable for Russia to seek control of the infrastructure used for its main source of export revenues in order to ensure reasonable tariffs and reliable maintenance and operation of the networks.

An examination of Russia's three-pronged energy policy offers insights on Moscow's perspective towards the Baltic states regarding gas. From Moscow's viewpoint, the three Baltic states are very similar as gas markets for at least three reasons. First, they are not gas transit states for Russia's deliveries to the West and thus, unlike the case of Ukraine, Moscow can interrupt gas supplies without causing disruptions to its other European customers. Second, the Kremlin consistently increased gas prices to the Baltic states throughout the 1990s and 2000s to the level of 'European' gas prices rather than those typically charged to former Soviet republics. ${ }^{98}$ From Russia's perspective, the Baltics have been part of the European market, at least from the pricing point of view, since the mid 2000s. Third, the Baltic states' gas market is of interest for direct investment, as demonstrated by Russian involvement in the national gas companies and gas-powered plants such as KHPP, as well as the presence in the region of Russian companies like Itera.

\section{Gazprom}

The main player in Russian gas politics is without a doubt the Russian national gas company Gazprom. It is the world's largest producer of natural gas and Russia's largest taxpayer and largest company constituting about $10 \%$ of the country's yearly economic activity. Though it is a joint-stock company, the state is the controlling stake-holder, making it a national gas company. ${ }^{99}$ Gazprom holds a dominant or monopoly position as a

\footnotetext{
${ }^{97}$ It is also questionable whether the Amber pipeline was a realistic project because it was always just a political and aspirational project and never attracted any serious investors.

${ }^{98}$ Smith 2004.

${ }^{99}$ As of 1 January 2012, Gazprom is owned by the Russian Federation (50\%) through the Federal Agency for
} 
supplier of natural gas in the Baltics, Central and Eastern Europe, and the former USSR, and its presence in Western European energy markets has been gradually increasing. Lastly, through its ties to Baltic gas distribution companies, Gazprom is also a player on downstream Baltic and EU gas markets. ${ }^{100}$

However, viewing Gazprom as simply the largest Russian company or a state-owned company is misleading. Gazprom has been described as 'one of the strongest institutions in the new Russia's economic and political environment. ${ }^{101}$ The claim could be taken further in that the management of Gazprom and the Kremlin often overlaps. ${ }^{102}$ Perhaps for this reason, Gazprom's activities were not always driven by profit-seeking as would be typical for similar companies elsewhere. ${ }^{103}$ In the Putin years, Gazprom has operated under the socalled national champion concept, where large companies in strategic sectors are expected to seek profit, but also to advance Russia's national interests and display responsibility towards the interests of the Russian state. Until 2008, Gazprom's domestic sales of gas at below the cost of production and delivery (as a form of public subsidy) served as one example. Yet by 2010 many of these aspects have changed and Gazprom has raised prices both domestically and for many of its neighbouring states such as the Baltics that used to enjoy preferential prices. ${ }^{104}$ Nevertheless Gazprom's commercial and non-commercial interests remain difficult to disaggregate particularly in the CIS, the Baltic states, and other countries of Central and Eastern Europe. In terms of investment strategy, Gazprom has openly stated that the Baltic states constitute one of the most important regions that the company targets. ${ }^{105}$ These interests must be more politically driven rather than commercially since in 2011 the tiny gas markets of the three Baltic states accounted for less than $3.2 \%$ of the volume of Gazprom's sales to Europe.

Federal Property Management (38.4\%), Rosneftegaz (10.7\%), Rosgazifikatsiya (0.9\%). Other investors include ADR holders (28.4\%), and other registered entities (21.6\%). Information from the Gazprom website, $<$ www.gazprom.com>.

${ }^{100}$ Łoskot-Strachota and Pełczyńska-Nałęcz 2008, p. 2.

${ }^{101}$ Kriukov and Moe, 1996, p.1. This judgement, made 15 years ago, is probably still correct but the context has changed significantly. For an account of how Gazprom's position has changed in Russian gas markets see Henderson 2010 and Henderson 2012.

${ }^{102}$ Russian President Dmitry Medvedev was Gazprom's Chairman of the Board in 2000, Deputy Chairman from 2001-2002, and served on the Board of Directors between 2002 and 2008.

${ }^{103}$ Kriukov and Moe 1996, p.38.

${ }^{104}$ See Henderson 2011.

105 "Gazprom finalized the Deal on Lietuvos Dujos' Stake". 


\section{Conclusion}

To this day the three Baltic states remain wholly dependent on Russian gas. Compared to other EU member states, Gazprom has had its greatest success in consolidating its interests in the Baltic gas sector, despite the fears expressed by the Baltic states of being dependent on Russia. This stands in great contrast to the general perception that in the EU the Baltic states are the most hostile towards and fearful of Russia in foreign policy and in economic partnerships. Amongst the neighbouring EU member states, Finland's Gazum Oy is the only national gas company where Gazprom is a major investor. The success of Russian investment in the gas sector is also notable when compared to the Baltic oil sector, particularly the greater ability of Latvia and Lithuania to resist Russian investment in their strategic oil assets. In many respects the outcome is not surprising. Lack of domestic energy resources, the inability to implement diversification projects, the high cost of alternatives, the structural conditions of the Baltic gas markets, and the strong influence of Gazprom-friendly business interests are the main reasons for this outcome.

In response to these conditions there is a very strong perception in the Baltic states that reliance on Russian gas makes them insecure and that a threat of a supply interruption or price discrimination is ever-present. However until the European Commission's investigation of 2012, this was primarily a local political view which was not supported by empirical evidence of actual interruption or, until 2008, of price discrimination. Despite the vulnerability of the Baltic gas sector, Russia has not resorted to overtly aggressive moves to date. Though on occasion Russia has cut off gas supplies to Belarus and Ukraine, and has permanently closed several oil pipelines supplying the Baltics, it has not engaged in gas wars with the Baltic states since the early 1990s. Even then there was a limit to what these actions accomplished. For example, in 1993 when Russia cut gas supplies to Estonia in an effort to change its citizenship policies the cut only lasted one day and failed to alter Tallinn's position. Since 1993, gas supplies have consistently remained stable. In terms of gas pricing, although the Baltic states believe they have been strong-armed by Gazprom, it could be argued that the Baltic countries sought independence from Russia and should expect to be treated in the same way as other European countries in relation to gas. In the period between 1991 and 2008 they received gas at lower prices than other European countries, and though there has been allegations of about price discrimination against the Baltics since 2008, this has been difficult to prove. Certainly the outcome of the European Commission's investigation and Lithuania's case against Gazprom in international arbitrage will challenge Gazprom's existing pricing mechanisms to the Baltic states and beyond. 
Beyond pricing, where Estonia, Latvia and Lithuania do have reason for concern is in the fact that Russia continues to insist upon its presumptive right to maintain a guiding influence on areas of Baltic gas policies deemed important to Moscow's interests, and to use Russian gas as a tool of political influence. One can argue that there is nothing illegitimate about a foreign state using soft power, lobbying, economic policy and cultural ties to advance its national objectives. Likewise, the region's energy dependency is a product of what had been a tight interdependence during the Soviet period, and it is not astonishing that Russia would retain an interest in the energy policies of successor states that, after 1991, became transit corridors for its oil exports to Europe. The problem in this case is that Russia's manner of pursuing these policy objectives impinges upon important areas of national sovereignty and energy security, and undermines core interests of the target states. Russia's and Gazprom's methods include covert methods of co-opting Kremlin-friendly diaspora, business interests, and political groups by setting the agenda of these groups to support Moscow's objectives rather than the interests of the countries in question. The fact that Moscow-led shadow economics and shadow politics have not receded following the three countries' accession to the EU further highlights the challenge this poses. ${ }^{106}$

Yet the blame cannot be shifted wholly to Russia. The context of the Baltic-Russian gas relationship is also shaped by the fact that many of the weaknesses that constrain the Baltic states are self-induced. Throughout this paper, attention has been drawn to the fact that in twenty years the Baltic states have failed to alter their gas predicament. Despite many pronouncements and memoranda, governments have not implemented gas diversification projects. The persistence of energy dependence is a reflection of the failure of Baltic elites to address the vulnerabilities that they have inherited. It seems that given the cost and the difficulty of achieving alternative gas supply routes to the Baltic countries, Russian gas has remained the only economic solution to date. Even the recent challenges to the status quo to the Baltic gas sector - BEMIP, ownership unbundling, investigation into Gazprom's monopolistic practises - have all been spearheaded by the European Commission.

Despite the consolidation of its interests in the Baltic gas markets, Russia's attempts to maintain the Baltics in its energy sphere of influence, has not been particularly successful. Contrary to Gazprom's and Moscow's preferences and efforts, the Baltics have chosen a strategic direction of energy diversification. Within the present decade, the Baltic countries may get an alternative source of gas via LNG. While this is likely to be delayed, on current

\footnotetext{
${ }^{106}$ Grigas, 2012.
} 
projections, a floating and possibly a land-based LNG terminal may eventually be built. While an LNG terminal will not guarantee lower gas prices - due to fluctuating world LNG prices the Baltic states may at times end up paying more for LNG compared to Russian gas - the terminal will place the Baltics in a stronger bargaining position vis-à-vis Moscow. Even if Russian gas prices remain more favourable and the LNG terminal remains largely unused, as a last resort gas supply route and a 'hedge' it will provide the Baltics greater gas security. With an LNG terminal as backup, threats of gas interruptions from Moscow would lose their coercive power, and thus become even more unlikely. Likewise, there remains no motivation for Russia to cut off the Baltics if they can simply turn to another country to buy gas. Admittedly Russia has not interrupted gas supplies to the Baltics since the early 1990s, but the implicit threat has always existed at least in the minds of the Baltic states.

With the arrival of LNG, Russian gas interests will lose some of their influence in the Baltic economies and political systems. As long as the LNG terminals are not acquired by Russian business interests, the risk of shadow politics, and opaque party financing should be reduced. Furthermore, if unbundling of Gazprom's assets in the Baltic states succeeds, it will have a similar effect of reducing Gazprom's influence. However, as was demonstrated with private gas distribution companies, the risk remains that assets not owned directly by Gazprom, but by Gazprom-friendly companies, are open to Russian government and/or Gazprom influence. Lastly, if the new Lithuanian nuclear power plant at Visaginas is built as planned by 2020 , the Baltic region overall will become a little less reliant on gas as an energy source. Meanwhile, if the Baltic states are to progress towards implementing their agenda of energy diversification and energy security, they will have to expect less hand-holding from the EU in the near term as Brussels is pre-occupied with Eurozone financial turmoil. Once they do succeed in diversifying their energy sources and routes, the Baltics will finally feel that the last vestiges of Soviet imperialism have been broken. For Russian gas remains in the minds of the Baltic countries a constant reminder and symbol of Soviet subjugation. The price of freedom from Russian gas will be high and the question remains whether the Baltics will be able and willing to pay for alternative supplies. It is likely that the EU may end up subsidizing diversification projects as a political gesture to finally link the Baltic states with the European energy sector, and demonstrate political independence from Russian gas. 


\section{Appendix}

\section{The privatization of Baltic gas companies - an historical overview (1991- 2004)}

The privatization of Baltic national gas companies and the growth in share ownership by Gazprom demonstrates the interplay between the structural gas sector conditions, domestic interest groups and Russia's policies. The three privatization case studies that follow show how these factors determine Baltic policies towards Russia and Gazprom's investment in the gas sector. To assess the foreign policies and the gas policies of the Baltic states towards Russia, this study employs a typology based on two axes: cooperative to adversarial; and pragmatic to principled.

Cooperative foreign policy is defined as a policy in which a state coordinates its policies in keeping with the actual or anticipated preferences of another actor. ${ }^{107}$ Policy coordination can involve bargaining or negotiations or simply adoption. ${ }^{108}$ A cooperative Baltic gas policy towards Russia means that Russia is perceived as a potential partner in the gas sector and a welcomed investor.

Adversarial foreign policy, on the other hand, entails a policy that challenges the preferences of the other state. Adversarial Baltic foreign policies towards Russia are understood as policies in which Russia is perceived as a potential threat and unwelcomed investor in the gas sector.

Pragmatic foreign policy denotes a policy formed with reference to calculated costs of the benefits of cooperation versus non-cooperation. In this study it will mean Baltic policies based on economic and political considerations rather than partisan preferences.

The opposite of pragmatic policy is principled foreign policy which is defined as a policy driven by the partisan preferences of political forces and is based on party dogma, beliefs, culture and values. ${ }^{109}$ In the Baltic states, it means that policy is influenced by the partisan preferences of the political right and the political left.

When comparing policies amongst the three Baltic states in the gas sector using the cooperative/adversarial and pragmatic/principled indices, clear divergence in policies can be discerned. Estonian policies towards investment in the gas sector fall in the middle of the foreign investment policy spectrum and can be described as liberal and 'open for

\footnotetext{
${ }^{107}$ Axelrod and Keohane 1986, p.226; Keohane 1984, pp.12, 51-55.

${ }^{108}$ Lindblom 1965.

${ }^{109}$ With regard to constructivist frameworks to understand these ideational variables of beliefs, culture, and values, this work will reflect the view that such subjective factors mediate our understanding of our interests, but for the purpose of this study I will not engage in an intensive deconstruction of the role of those factors and instead bracket them to focus on concrete outcomes.
} 
business.' They can also be described as the most cooperative and pragmatic of the three Baltic states. Latvia is less open to Russian investment in its gas sector than Estonia but more open than Lithuania. Riga's privatization policies can be described as mildly adversarial and moderately principled vis-à-vis Russian investment in its gas sector. In the gas sector, Lithuania's policy towards Russian investment exhibits higher levels of resistance than those evident in Estonia and Latvia. Indeed, Vilnius' policies towards Gazprom investment can be described as adversarial and principled until 2004 when they became relatively more cooperative and pragmatic, converging towards the policies of Latvia and Estonia.

While the privatizations of Eesti Gaas, Latvijas Gāze, and Lietuvos Dujos lend themselves to comparison because of the inherent similarities of the three gas sectors, this also poses some difficulties. The main contrast between the three cases is the difference in the timing of the privatizations, arising from the fact that the three privatizations were conditioned by very different sets of geopolitical circumstances. Gazprom's Estonian acquisition occurred when the country was still in the first stages of sovereignty building from 1990 to 1995. During those years Tallinn focused on the withdrawal of Soviet military from Estonian territory and international recognition of its independence. Four years later, at the time of the privatization of Latvijas Gāze, Latvia was already in the second stage of state building (1995 to 2004) as it sought to become a member of trans-Atlantic organizations. Finally, in the Lithuanian case, the privatization was finalized in 2004, following EU and NATO accession during the third stage of Baltic state consolidation (2004 to 2012).

\section{Privatizing Eesti Gaas}

In comparison to Latvia and Lithuania, Estonia pursued the most cooperative and pragmatic policies towards Russian investment in its gas sector by demonstrating the least resistance to Gazprom's privatization of Estonian national gas company Eesti Gaas. Tallinn's policies were driven primarily by two factors: the neoliberal economic views of the parties in power and the timing of the privatization, which occurred when Estonia was in the sovereignty building stage of 1990-1995. When, in January 1993, Gazprom acquired $30 \%$ of the Estonian national gas company Eesti Gaas, it was the first major acquisition by the Russian gas monopoly in the Baltic states. ${ }^{110}$ The sale was motivated primarily by commercial rather than political considerations ${ }^{111}$ even though Eesti Gaas had been a strategically important company in Estonia since the Soviet period. Being the sole distributor of gas in a country where natural gas provides over $90 \%$ of the energy for

\footnotetext{
${ }^{110}$ The Estonian state retained $70 \%$ of Eesti Gaas shares.

${ }^{111}$ Interviews with Baltic diplomats, Vilnius, April 1997 and January 2010.
} 
Estonia's district heating stations, ${ }^{112}$ Eesti Gaas has had an impact on nearly the entire Estonian population.

\section{The Domestic Politics of the Eesti Gaas Sale}

The privatization of Eesti Gaas was a government-led affair, and the process was determined by the ideologies of the centre right government. In April 1992, a decision was reached by the Estonian government to transform Eesti Gaas into a public limited company where $70 \%$ of the shares would belong to the Estonian state and $30 \%$ to the Russian company Gazprom. The interim Estonian government at the time was led by Prime Minister Tiit Vähi, a figure who embraced a neoliberal ideology ${ }^{113}$ through which he hoped to transform Estonia from a centrally planned economy into a free market economy. Vähi accordingly created the Estonian Privatization Agency, to sell government-owned assets including Eesti Gaas.

However, by January 1993 when the Foundation Agreement to create a public limited company - Eesti Gaas - was signed, there was a new rightist government in power led by Prime Minister Mart Laar of the Christian Democratic Party (later Pro Patria). Laar was a 31-year-old free marketeer who referred to himself as 'Thatcher's grandson.' During this period, Eesti Gaas shares were transferred to Gazprom and the Estonian state. Like Vähi, Laar's government also embarked on an ambitious program of market reform, involving large scale privatization, with the privatization of Eesti Gaas an obvious choice. In 1995, under a new government led by independent Andres Tarand, privatization continued, with additional Eesti Gaas shares sold to Ruhrgas (14.67\%) and the Baltic Republic Fund $(7.5 \%) .{ }^{114}$ The decision to privatize Eesti Gaas was thus greatly determined by the free market, neoliberal views of Estonia's policy elites including Vähi, Laar, and Tarand.

The decision to allow Gazprom to acquire 30\% of Eesti Gaas may seem surprising given Estonia's strongly Western tendencies in the early 1990s and the rule of centre right parties that were cautious of Russia as a partner. The Estonian privatization case does not support the general assumption that rightist political parties would pursue adversarial policies towards Russia and resist investment by Russian companies. Three factors explain Estonian government policies. First, the Estonian right (in contrast to the Latvian and

\footnotetext{
112 "An Energy Overview of the Republic of the Estonia", 2003.

${ }^{113}$ Neoliberal is used to refer to the strand of liberal economic thinking that believes a state should have minimal influence over the economy, which should function based on market forces.

${ }^{114}$ Kilvits, Purju, and Pädam 2005, p.63.
} 
Lithuanian right) was characterised by its neoliberal economic ideology which favoured foreign investment in general. Second, rightist political governments often have fewer domestic constraints in their pursuit of cooperative policies towards the Kremlin, because they will not be criticized for being 'soft on Moscow' as would political parties of the left. Third, in their policies towards Moscow, the Estonian Popular Front and the first Prime Minister of Estonia, Edgar Savisaar, pursued more moderate policies than their counterparts in Lithuania and to some extent Latvia. ${ }^{115}$ It is possible that if parties of the political left had been in power in 1993, it is less likely that Gazprom would have acquired Eesti Gaas. First, parties of the left would have been less likely to launch privatization of state-owned companies. Second, though their partisan preferences would have favoured Russian investors, they could have felt constrained to pursue cooperative policies towards Moscow because of the need to be attentive to public wariness of their communist roots.

The stage of Estonia's state development during the privatization process was also a major factor in influencing policy options. Estonia's geo-strategic position was very different during the privatization of Eesti Gaas in 1993, than that of Latvia and Lithuania at the time of the privatization of Latvijas Gāze in 1997 and Lietuvos Dujos in 2004. The Estonian government privatized Eesti Gaas soon after (re-)establishing statehood, at a time when it was engaged in the sovereignty building processes of 1990 to 1995 . Indeed, during the 1992-1993 period, the former Soviet army was still present on Estonian territory, ${ }^{116}$ and there was a Russian military presence at the Estonian Paldiski nuclear submarine training base until September 1995. In contrast, by the time Latvia privatized its national gas company in 1997, Latvian sovereignty was established, statehood was being consolidated and the former Soviet army was no longer present. Last but not least, the geo-strategic position of the Baltic states had changed dramatically by the time Lithuania started its privatization in 2004 - the year the Baltics joined the European Union and NATO. Thus, in the political and economic climate of 1992, Tallinn's decision to allow the only supplier of gas to Estonia - Gazprom - to become the first foreign investor in Eesti Gaas seemed politically prudent. Furthermore, in the early statehood period, it would have been very difficult to attract Western foreign investment because the Baltic states were still viewed by Western markets as politically risky, former Soviet republics, and Moscow-satellite states. For instance, though the French national champion Gaz de France expressed some interest in acquiring shares of Eesti Gaas, it did not make a bid.

\footnotetext{
${ }^{115}$ For instance, the Popular Front of Estonia, in comparison to a similar movement - Sajūdis - in Lithuania, pursued a step-by-step approach towards independence and recognized Estonia's economic and political dependence on Russia.

${ }^{116}$ The former Soviet army left Estonia and Latvia in August 1994.
} 
In addition to the liberal policies of the Estonian government and the stage of state development, the general context of Estonian-Russian relations also influenced Tallinn's policies towards the Gazprom acquisition. In January 1993, Tallinn turned over 30\% of shares to Gazprom after months of tension with Moscow, related to Estonia's language and citizenship policies, which spurred the Russian Duma, in July 1992, to call for economic sanctions against Estonia citing the mistreatment of Russian minorities. By the autumn, 'protection of compatriots' had become the official policy of the Kremlin. In November 1992, a week after president Boris Yeltsin ordered a halt to the Russian troop withdrawal from the Baltics, Moscow threatened to cut off deliveries of natural gas unless the Baltic States agreed to a new plan to finance the troops. ${ }^{117}$ Though the Kremlin did not officially link the matter to Gazprom investment in Eesti Gaas and ongoing supply of gas to Estonia, it is likely that Estonia believed investment in its national distribution company by the only gas supplier would ensure stable gas supplies in the future.

However, this did not prove to be the case. Gazprom's first halt in gas supplies came in June 1993 after Gazprom had acquired 30\% of the shares in Eesti Gaas in January of the same year. ${ }^{118}$ The gas cut came as the Estonian government under Laar was considering an exclusionary citizenship law that would have required most Russian speakers to apply for residency ${ }^{119}$ or risk deportation. The Kremlin vowed it might intervene to protect the rights of ethnic Russians in the 'near abroad.' During this time, Gazprom stopped supplies to Estonia for four days. However, there was a limit to the pressure Gazprom could put on Estonia since the country was able to receive gas from the underground storage facility in Latvia. Thus, Gazprom would have had to shut down gas supplies to both Latvia and Estonia for a significant period in order to disrupt the Estonian market. Still, in the wake of this flexing of muscles and given the moral suasion of regional organizations, a modified version of Estonian citizenship law passed in July 1993.

Significantly, revisions in the new version addressed the objections of the Council of Europe, but not those which had been articulated by Russia. Because the law denied citizenship to retired Russian officers it fell short of Moscow's demands, and Gazprom halted supplies of gas for another four days. Tallinn responded by cutting food supplies to Russian military bases on its territories. ${ }^{120}$ The stand-off revealed that in spite of having

\footnotetext{
117 "Russian Gas Deliveries to Baltic Region Halted".

118 "Russian Gas Deliveries to Baltic Region Halted".

119 The law was applicable to approximately 500,000 former Soviet citizens who had emigrated to Estonia following Estonia's occupation by the Soviet Union.

${ }^{120}$ Drezner 1999, p.226.
} 
shares in Eesti Gaas and despite being the sole supplier of gas to Estonia, Gazprom failed to provide the Kremlin with effective leverage to alter Tallinn's minority policies in 1993. Calls by the Russian Duma for economic sanctions against Estonia and Latvia were repeated in March 1995, July 1996, and January 1997 by Russian Foreign Minister Yevgeny Primakov. ${ }^{121}$ These examples show that Moscow was willing to utilize Estonia's economic and energy dependence on Russia in order to pressure Tallinn with regard to its citizenship law, minority treatment, and Russian troop withdrawal. Yet, in all three instances, Moscow failed to gain significant leverage over Tallinn.

Third party states outside Russia or Estonia did not play a significant role in the privatization of Eesti Gaas. However, one could argue that Estonian political elites were highly influenced in the early 1990s by neoliberal economic thinking and what could be described as the "Washington consensus". A number of Central and East European countries in the early 1990s were advised by international organizations like the World Bank and the International Monetary Fund which promoted market-driven reforms and the reduction of the state role in national economies. Thus, rapid and massive privatization of key infrastructure assets and companies such as Eesti Gaas was a policy outcome favoured by neoliberal thinking.

\section{Subsequent Sales of Eesti Gaas Shares}

Gazprom's acquisition of Eesti Gaas became a template for the company's future investments in the Baltic states where Gazprom would initially acquire a minority but blocking stake and gradually increase its stake. ${ }^{122}$ Throughout Gazprom's expansionism, Tallinn did not demonstrate any resistance to the Russian investor despite changing governments and external circumstances. Interestingly, unlike in many other examples of Gazprom expansionism, acquisition of additional shares of Eesti Gaas was not a top priority for the Gazprom management for most of the 1990s following the initial acquisition in 1993. ${ }^{123}$ During the second stage of privatization of 1996 to 1999, when the Estonian state decided to sell off its shares of Eesti Gaas, Gazprom did not seek to acquire additional shares. ${ }^{124}$ The decision to not invest further in Eesti Gaas in the late 1990s was simply a function of the Russian financial crisis and Gazprom's preoccupation with acquiring an initial stake in Latvian Latvijas Gāze (see below). However, it appears that

\footnotetext{
${ }^{121}$ Kauppila 1999.

${ }^{122}$ Smith 2004, p.31.

${ }^{123}$ Kilvits, Purju, and Pädam 2005, p.66.

${ }^{124}$ Kilvits, Purju, and Pädam 2005, p.67.
} 
Gazprom sought to have greater control of Eesti Gaas through its unofficial partner companies and was not willing to give up control to other shareholders. For instance, Gazprom's reported ally in the 1990s - Itera Latvija - acquired 10\% of Eesti Gaas from Baltic Republics Fund, a private investment fund, in March 1999. With Itera Latvija holding $10 \%$ of shares and Gazprom another 30\%, Russian companies came to control more than $40 \%$ of Eesti Gaas. By the late 2000s, Gazprom increased its shares to $37 \%$ by slowly buying shares owned by small investors. It appears that owning a controlling share of Eesti Gaas was politically rather than commercially important for Gazprom. Gas sales to Estonia are small, and there is no onward shipment of gas. Being the only supplier of natural gas to Estonia, Gazprom already held significant sway over Eesti Gaas and the Estonian gas market. However, the ownership of Eesti Gaas shares enabled Gazprom to create vested interests to act in its favour on Estonia's political and economic stage.

Table 5: Main privatization stages of Eesti Gaas

\begin{tabular}{|c|c|l|}
\hline Year & $\begin{array}{c}\text { \% Shares privatized from Estonian } \\
\text { state }\end{array}$ & Acquiring Entity (State of Origin) \\
\hline 1993 & $30 \%$ & Gazprom (Russia) \\
\hline 1994 & $7.5 \%$ & Private Investors (Estonia) \\
\hline 1995 & $14.67 \%$ & E.ON Ruhrgas (Germany) \\
\hline 1995 & $7.5 \%$ & Baltic Republic Fund (UK) \\
\hline 1996 & $14.67 \%-->21 \%$ & E.ON Ruhrgas (Germany) \\
\hline 1998 & $10 \%$ & Neste/Fortum Oil and Gas (Finland) \\
\hline 1999 & $21 \%-->32 \%$ & E.ON Ruhrgas (Germany) \\
\hline 1999 & $\begin{array}{c}10 \% \\
\text { (from Baltic Republic Fund) }\end{array}$ & Itera Latvija (Russia) \\
\hline $2000 \mathrm{~s}$ & $\begin{array}{c}30 \%-->37 \% \\
\text { (from private investors) }\end{array}$ & Gazprom (Russia) \\
\hline
\end{tabular}

Source: Eesti Gaas company website 2012.

\section{Summary}

The analysis of Gazprom's acquisition of a controlling stake in Eesti Gaas highlights several key factors in Estonian foreign policy-making towards Russia. First, it does not support the idea that rightist political forces always pursued adversarial policies towards Russia and Russian investment. This episode demonstrates that the opposite can in fact be the case: the Estonian political right indirectly favoured Gazprom's acquisition due to its neoliberal ideology, which favoured privatization of state-owned enterprises to foreign investors. Also, given their credentials as leaders of the independence movement, the Estonian political right was in a better position vis-à-vis the public to cooperate with Moscow than would have been the Estonian political left. Timing - and internal and external circumstances - also played a significant role in shaping Tallinn's policy options 
in the early 1990s. Tense relations over Estonia's Russian minority in the early 1990s and the concomitant threat of economic blockade by Russia may also have had some - albeit limited - impact on the Estonian government's willingness to pursue cooperative policies towards Russian investment in order to ensure a stable supply of gas. There is no evidence, however, to suggest that domestic business interests played a role in influencing Estonian policies. The primary reasons were that in 1992-93, business interests were still new and weak and Eesti Gaas, which had been created recently, did not have a strong influence in domestic politics or established links with Gazprom. Likewise, the Russian minority was preoccupied with language and citizenship issues and did not play a role in Estonian policies towards Russian investment.

\section{Privatizing Latvijas Gāze}

Latvian policies towards Russian investment in its gas sector fell between the Lithuanian and Estonian policies. Latvian policies were characterised by greater pragmatism and cooperation than those of Lithuania, but fell short of Estonian policies. Riga's policies were also driven by domestic politics, existing gas infrastructure, and Russian policies. Unlike in Estonia, local gas interests were influential in Riga's policy making.

After several years of pressurising the Latvian government, Gazprom was able to acquire 16.25\% of Latvijas Gāze in April 1997, four years after its acquisition of Eesti Gaas and just prior to the Russian financial crisis of 1998. During this first round of privatization, Germany's E.ON Ruhrgas acquired the other $16.25 \%$ share on offer. The privatization followed the rules set out by the Latvian Privatization Agency (LPA) proposed that Latvijas Gāze, which had become a joint stock company in 1994, would be privatized by attracting two investors. According to the rules of the LPA, one of the investors had to be a gas supplier. Gazprom, as Latvia's only supplier of gas and the only supplier with infrastructure to deliver, was realistically the only prospective buyer which could meet the LPA requirements. The privatization rules also stipulated that the second investor had to be a 'strategic investor,' and E.ON Ruhrgas went on to fill this role. Thus, Gazprom and E.ON Ruhrgas, which had already become primary investors in Eesti Gaas in 1993 and 1995, respectively, became the most likely investors in Latvijas Gāze at the time bidding was opened in 1997.

As in the case of Estonia, Gazprom's initial investment of $16.25 \%$ gradually increased, to $34 \%$ by 2005 . Furthermore, through the acquisition by its ally Itera Latvija of a $16 \%$ stake, Gazprom and its affiliates acquired a controlling 50\% share of Latvijas Gāze by 2010. This meant that Gazprom and Itera Latvija could have more influence in the company than E.ON Ruhrgas which owned $47 \%$ of the shares. 
Unlike in Estonia, the privatization process of Latvijas Gāze was a politicized and drawn out affair. As the only natural gas transmission, storage, distribution, and sales operator in Latvia, Latvijas Gāze has been considered a strategic national energy company since the re-establishment of Latvia's independence. The company supplies natural gas to 442,000 customers in Latvia or nearly a quarter of the Latvian population. Latvijas Gāze also owns the strategically important Inčukalns underground gas storage facility. However between 1990 and 1993, with the break-up of Soviet-era industry in Latvia, national gas consumption declined by $52 \%$. By 1994, Latvijas Gāze was taking large credits from the Bank of Latvia and the World Bank to postpone insolvency. To salvage this strategic asset, the state decided to transform Latvijas Gāze into a state joint stock company and assigned it for privatization in 1993.

\section{The Domestic Politics of the Latvijas Gäze Sale in the 1990s}

Latvian policies towards Russian investment in its gas sector were primarily driven by the political orientation and preferences of the ruling centre right parties and leaders. As in Estonia, the stage of the state's development as well as its relations with Russia also influenced policy making. During the first round of privatization in April 1997, Latvia's domestic political environment was moderately favourable to an acquisition by Gazprom. When the Latvian state sold $16.25 \%$ of Latvijas Gāze, the Latvian government was a centre right coalition with more moderate views towards Russia than might be expected of a rightist government. This is because the government was led by the Latvian Way political party which can be described as economically conservative but centrist in its foreign policy and therefore less sensitive towards Russian investment. Privatization took place under the leadership of the non-partisan businessman Prime Minister Andris Šḳēle. Šķēle's approach to privatization was more driven by commercial considerations than by political or security concerns, an attitude which facilitated acquisition of shares of Latvijas Gāze by Gazprom. Šksele's mindset reflected the Estonian elite's liberal, 'open for business' approach espoused by leaders such as Mart Laar.

It is conceivable that Gazprom would have had a more difficult time acquiring shares of Latvijas Gāze under different leadership. In fact, by August 1997, Šķēe was replaced as Prime Minister by Guntars Krasts from the For Fatherland and Freedom (FFF) political party. FFF was the political party furthest to the right in Latvia and strongly opposed closer economic and political ties with Russia. It is fairly certain that Krasts would have resisted Gazprom's acquisition of the minority stake of $16.25 \%$. The receptivity of Latvian Way to Gazprom investment further reveals that centre right parties in neither Estonia nor Latvia consistently pursued adversarial policies towards Russia and Russian investment. Both 
privatizations to Gazprom occurred under centre right party leadership, though not under far right parties. Also, as in the Estonian case, the Latvian experience highlighted the importance of individual leadership in terms of the role played by neoliberal Mart Laar and businessman Andris Šksēle.

Timing was another factor that set the context for Latvia's policy choices vis-à-vis Russia. In 1997, Latvia was immersed in the processes of state development, a period which lasted from 1995 to 2004. The prime goals were to consolidate independence and join Western organizations. Latvia's geostrategic position at the time of the 1997 privatization, was considerably better than that of Estonia when it privatized the first shares of Eesti Gaas in 1993. By 1997, the former Soviet army was no longer in the territories of the Baltic states. The state's sovereignty was ensured, and recognized by international organizations, and applications for EU and NATO membership were in progress. The Russian military was scheduled to leave the Skrunda base in Latvia by 1998. Thus, one could argue that Latvia was in a moderately strong position to potentially resist Gazprom's overtures to acquire Latvijas Gāze, and yet it did not.

The reason for this may have been Latvia's evolving relations with Russia which leaned towards a more cooperative policy in this period. For example, in 1997, the Russian army was still at Latvia?s Skrunda military base, and the Latvian government did not want to risk a delay in the evacuation of the base. Thus, Riga's policies towards Russia were conditioned to be more cautious and cooperative. A further factor which weakened the Latvian government's position regarding Latvijas Gāze and encouraged more cooperative policies was the fact that the Latvian-Russian border treaty was not ratified, causing Latvia to avoid policies that could bring on Moscow's disfavour. ${ }^{125}$ The border agreement with Russia was of crucial importance to the Latvian political elites because without this agreement Latvia's membership application to the EU was jeopardized. This may explain why, in 1997 at a time when Gazprom was in the process of acquiring shares in Latvija Gāze, the Latvian and Russian government were engaged in the drafting of a border treaty. Negotiations between the two sides took place in February and March 1997 without much success. In August 1997, three months after Gazprom acquired its 16.25\% share, a draft border agreement was completed. ${ }^{126}$ The timing of the border agreement completion suggests that there was some linkage between Gazprom's acquisition of Latvijas Gāze and Moscow's willingness to finalize negotiations. Whilst it is unlikely that the border treaty was used to coerce the Latvian government into selling a large stake in Latvijas Gāze to

\footnotetext{
${ }^{125}$ Interview with anonymous Baltic diplomat, Vilnius, 13 July 2010.

126 "Latvian - Russian Draft Border Agreement Fully Harmonized".
} 
Gazprom, the outstanding necessity to reach border agreement was a factor favouring more cooperative policies towards Russia.

Another aspect of Latvian-Russian relations that influenced Riga's policies was that the privatization occurred simultaneously with Russian gas price hikes to Latvia and negotiations for a new gas contract. Already, in July 1994, Gazprom offered to reduce Latvia's gas bill in return for a 50\% stake in Latvijas Gāze. However, in this period Latvia was still deciding when and how it would privatize the company. According to Drezner, the main motivation behind the Latvian government's decision to sell $16.25 \%$ of Latvijas Gāze to Gazprom in April 1997 was to secure gas supply. ${ }^{127}$ Latvia's complete dependency on Gazprom for gas supplies which are crucial for its population and industry cannot be underestimated as a factor determining Latvia's policy options regarding the privatization.

Business lobbies also played a significant role in the Latvian government's preference for a cooperative and pragmatic policy towards Moscow regarding privatization. Former Foreign Minister Artis Pabriks (2004-2007) openly stated that that there were a number of stakeholders in Latvia who were lobbying on behalf of Russia's economic and political interests. ${ }^{128}$ In the summer of 1997, the networks between political elites and business lobbies became apparent in a series of corruption scandals that resulted in the resignations of four ministers. The most illustrative was Škēele's demand for a vote of non-confidence in Minister of Transport Vilis Krištopans, one of the most influential members of Latvian Way centre right political party. Krištopans was accused of violating the anti-corruption law by sitting on the board of directors of LatRosTrans, a Latvian-Russian pipeline joint venture, and Interbaltija, a Latvian-Irish trading firm. In the same period, Latvia's prosecutor general examined conflict of interest cases involving more than 40 MPs but found no significant transgressions. ${ }^{129}$ Though suspicions and allegations have not been proven, the lack of separation between business and politics does suggest that business interests played a role in Latvian policies towards the privatization of Latvijas Gāze. Furthermore, it is widely believed among the Latvian analysts and media that Latvijas Gāze, Latvenergo, and Itera Latvija were influential players in the Latvian economy that favoured Russian investment due to their own close relationship with Gazprom. ${ }^{130}$

\footnotetext{
${ }^{127}$ Drezner 1999, p.223.

${ }^{128}$ Sloga 2008.

129 "Constitution Watch".

${ }^{130}$ Sprūds 2009, p.241.
} 
Itera Latvija was possibly the party most interested in the privatization of Latvijas Gāze. It was founded in 1996 at the beginning of the Latvijas Gāze privatization process for the alleged purpose of influencing the process and obtaining shares. By 1997, Itera Latvija was a sizable player in the Latvian gas sector providing $30 \%$ of Latvia's gas supplies and shaping the political and public debate on Latvian energy choices ${ }^{131}$. By 2004, Itera Latvija's shares of Latvijas Gāze were on a par with Gazprom, with both owning 25\%. One theory holds that for Gazprom, Itera was a tool to acquire more shares and control in Latvijas Gāze, as seen by the 2005 Itera sale of some of its shares to Gazprom. The conditions in Latvia stood in contrast to those of the privatization of Estonia's Eesti Gaas in 1993, wherein the political and legal environment and the lack of consolidation of local business made the Estonian government less susceptible to business interests.

A comparison of the course of events and outcomes in the privatization of Latvijas Gāze in 1997, and the attempted acquisition by Russian investors of port operator Ventspils Nafta (VN) in 1998 provides additional insights into the factors influencing Latvia's foreign policy towards Russia. In 1997, at the time of the privatization of Latvijas Gāze, VN was also partly privatized. However, VN remained a public joint stock company owned by Latvijas Naftas Tranzīts (LNT) with the Latvian government retaining a $43 \%$ stake. The most important differentiating factors between the privatization of VN and Latvijas Gāze were domestic politics and relations with Russia. LUKOIL's attempts to acquire VN took place during the rule of Prime Minister Guntars Krasts and his nationalist FFF party. As the most right wing political party, the FFF resisted LUKOIL's overtures on ideological grounds. They also reputedly received campaign contributions from VN, which resisted being acquired by a Russian investor. Despite the privatization of Latvijas Gāze to Gazprom in 1997, by 1998, Latvian-Russian relations reached an all time low. 1998 was characterised by protests by Russian-speakers in Riga (allegedly incited by Moscow) in March and intensified rhetoric from the Kremlin on the protection of 'compatriots., 132 Moscow's aggressive stance was met in kind by Latvian elites. The tensions increased the sense of vulnerability in the Latvian government, making it even less willing to permit the expansion of Russian influence in the country through the acquisition of VN.

As in Estonia and Lithuania, there was little direct influence of foreign states other than Russia over the privatization of the national gas company. However, the liberal thinking espoused by organizations such as the World Bank and the IMF(the Washington Consensus) played an important role in convincing Latvia that it must privatize Latvijas Gāze in order to have a functioning and economically viable national gas company. Since

\footnotetext{
${ }^{131}$ Sprūds 2009, p.242.

${ }^{132}$ Stranga 1998, pp.1-15.
} 
Latvijas Gāze was taking large credits from the World Bank to postpone insolvency in 1994, the World Bank played a role in encouraging its privatization.

\section{Subsequent Sales of Latvijas Gāze Shares}

Whilst the Latvian government was more at ease selling a minority rather than a majority share of Latvijas Gāze to a Russian investor, Gazprom gradually increased its stake in the Latvian gas company. By 2012, Gazprom owned 25\% and Itera Latvija controlled 25\%. The fact that Gazprom and Itera operated in tandem regarding Latvijas Gāze was demonstrated by their coordinated negotiations with the Latvian government in the 1990s and early 2000s. For instance, in 2002, Gazprom and Itera sought to raise the price of gas sold by Latvijas Gāze to consumers. They jointly challenged the decision of the government commission not to allow Latvijas Gāze to raise prices. Together they argued that the existing price level was not sufficient to ensure further investment in the company. ${ }^{133}$ Furthermore, Itera Latvija's strategic interest in owning a share in Latvijas Gāze was demonstrated by Itera's refusal to divest some of its shares to E.ON Ruhrgas, when the latter made that suggestion in May 2002. According to Itera Latvija chief Juris Savickis, the company did not consider selling its shares in Latvijas Gāze. ${ }^{134}$

Table 6: Main privatization stages of Latvijas Gāze

\begin{tabular}{|c|c|l|}
\hline Year & $\begin{array}{c}\text { \% Shares } \\
\text { privatized from } \\
\text { Latvian state }\end{array}$ & Acquiring Entity (State of Origin) \\
\hline 1997 & $16.25 \%$ & Gazprom (Russia) \\
\hline 1997 & $16.25 \%$ & E.ON Ruhrgas (Germany) \\
\hline 1999 & $10.2 \%$ & Itera Latvija (Russia) \\
\hline 2000 & $16.25 \%$ à42.65\% & E.ON Ruhrgas (Germany) \\
\hline 2000 & $10.2 \%$ à $21.4 \%$ & Itera Latvija (Russia) \\
\hline 2000 & $16.25 \%$ à $25 \%$ & Gazprom (Russia) \\
\hline Early $2000 \mathrm{~s}$ & $42.65 \%$ à $47 \%$ & E.ON Ruhrgas (Germany) \\
\hline 2004 & $21.4 \%$ à $25 \%$ & Itera Latvija (Russia) \\
\hline $2005-$ & $25 \%$ à $34 \%(f r o m$ & Gazprom (Russia) \\
present & Itera Latvija) & \\
\hline
\end{tabular}

Source: Latvijas Gāze company website 2012.

\footnotetext{
${ }^{133}$ Pirovska 2003.

${ }^{134}$ Interfax/BNS new report, 13 May 2002, Riga, Latvia.
} 


\section{Summary}

In sum, the privatization of Latvijas Gāze demonstrated that Latvian policies towards Russia and Russian investment were driven by domestic politics. The centre right leadership was not predisposed against Russian investment and that there were variations in the preferences of the political right. The moderate leadership of Škēle and Latvian Way facilitated cooperative policies towards Gazprom's acquisition of a minority shares in Latvijas Gāze. This decision was facilitated by the fact that Gazprom initially acquired only a minority stake, and that there were no alternative investors who could also supply gas to Latvia. The general context of relations with Russia, such as border agreement negotiations, gas supply contract renewal, and the Russian military presence at the Skrunda military base, also favoured cooperative and pragmatic policies towards Moscow. The importance of the context of relations with Russia for both Tallinn and Riga in formulating their policies towards investments by Gazprom demonstrates that there was clear - though not necessarily explicit - linkage in issue areas in the Estonian-Russian and LatvianRussian gas relationships. Whilst business interests did not play a role in Estonian policymaking regarding Gazprom, they did so in Latvia due to the stronger connections between business and politics, lack of transparency in the Latvian domestic system, and powerful vested interest groups tied to Latvijas Gāze, Latvenergo, and Itera Latvija. The precedent of Gazprom's acquisition of Eesti Gaas in Estonia also probably played a role in influencing Latvia's policies towards the Gazprom acquisition.

\section{Privatizing Lietuvos Dujos}

In contrast to Latvia and particularly Estonia, the privatization of Lithuanian national gas company Lietuvos Dujos was marked by highly adversarial and principled policies towards Russian investment. The privatization was a long and highly politicized process which started in 2000 and demonstrated the dominant role of the partisan preferences of domestic political parties and business interests. In 2000, Lietuvos Dujos was performing poorly with debts of $\$ 100$ million. Privatization offered a solution. The privatization process was staged in two phases, with each phase divesting $34 \%$ of the shares. Provisions for the first $34 \%$ sale were published in the fall of 2001 , and outlined that shares be allocated to a strategic foreign investor - a Western investor. The prime candidates as the strategic foreign investor were Gaz de France and E.ON Ruhrgas. E.ON Ruhrgas with its close connections to Gazprom (it owned 4\% of Gazprom in 2000) seemed the best contender. With Gaz de France pulling out of the race at the end of 2001, E.ON Ruhrgas became the only contender, and acquired the 34\% stake in 2002. 
The second $34 \%$ share was allocated by the privatization provisions to a commodity supplier. Lietuvos Dujos already stated in 2000 that requirements for the possible investor would be the ability to guarantee gas supplies and the possibility to provide alternative sources of gas. ${ }^{135}$ However, with no alternative gas pipeline infrastructure, no Western investor could fully guarantee gas supplies. As Remigijus Šimašius ${ }^{136}$ remarked, if one of the provisions required Lietuvos Dujos to be sold to a gas provider, who else could that actor be other than Gazprom? The privatization provisions almost ensured that there would only be one buyer to meet this demand and therefore placed that buyer in a stronger position in terms of price and the number of shares it sought to acquire. ${ }^{137}$ The only other possible investor that was a gas provider, had access to Gazprom pipelines, and was interested in Lietuvos Dujos was another Russian company, Itera. But the Lithuanian government did not allow Itera to bid since the tender conditions specified potential investors in Lietuvos Dujos must have at least ten years of experience in managing gas distribution systems. ${ }^{138}$ It is likely that the condition was drawn up especially to exclude Itera which otherwise would have been a contender as it already had shares in both Eesti Gaas and Latvijas Gāze. The result was that, after intense political debate, the Lithuanian State Property Fund allowed Gazprom to participate in the tender, and in 2004, Gazprom purchased the $34 \%$ share package.

Lietuvos Dujos - the national gas distributor - was a strategic national enterprise but it played a less dominant role in the Lithuanian gas sector than Eesti Gaas in the Estonian or Latvijas Gāze in the Latvian gas sector prior to 2004. The main difference was that the Lithuanian natural gas market had been open to competition since 1992, whilst the Estonian and Latvian gas markets were not. Lithuanian gas distributors such as Dujotekana, Stella Vitae, and Vikonda were sizable players in the market and rivals of Lietuvos Dujos. ${ }^{139}$ In 1999, Gazprom even briefly stopped supplying Lietuvos Dujos because of the latter's unpaid debts. ${ }^{140}$ Before Gazprom was able to acquire shares in Lietuvos Dujos, it viewed it as a competitor to the distributing companies with which

\footnotetext{
135 Vytenis Junevičius, advisor to Lietuvos Dujos and head of the privatization contest, cited in Bagdanavičiūtė 2000.

${ }^{136}$ At the time, Šimašius was an analyst for the Lithuanian Free Market Institute and Minister of Justice since 2008.

137 Šimašius 2002.

138 "Lithuania Approves Plans for Privatisation of Lietuvos Dujos".

${ }^{139}$ As the state operator Lietuvos Dujos was not in a monopoly position as a gas distributor in the 1990s, and its market share progressively fell to $22 \%$ in 2002 .

${ }^{140}$ Pirovska 2003.
} 
Gazprom had a close relationship. Following Gazprom's acquisition,Lietuvos Dujos' share of the market increased at the expense of the other companies to $45 \%$; assuming the same importance as Eesti Gaas in Estonia, and Latvijas Gāze in Latvia.

\section{The Domestic Politics of the Lietuvos Dujos Privatization}

From the beginning of discussions to privatize Lietuvos Dujos in 2000 to the completion of the sale to Gazprom in 2004, the privatization of Lietuvos Dujos was marked by heated domestic political debates. This resulted in the delay of the transaction by four years, although it was initially assumed that the privatization would be completed in $2000 .^{141}$ The privatization overlapped with the 2000 to 2004 rule of a centre left government led by the Social Democrats under the premiership of Algirdas Brazauskas (July 2001-June 2006). The Social Democrats favoured cooperative political and economic relations with Moscow, including openness to Russian investment in Lithuanian energy assets. Behind the ideology was the rationale that since Russia was the primary supplier of gas and oil to Lithuania, only Russian companies could guarantee supply of raw materials to Lithuanian energy enterprises. Algirdas Brazauskas, the former Lithuanian Communist Party leader, a former President, and head of the Social Democrats also prided himself on his good relations with Moscow. This stance corresponded to the strong correlation in Lithuania between the sale of strategic energy assets to Russian investors when Social Democrats were in power (i.e. Mažeikių Nafta to Yukos in 2003, Lietuvos Dujos to Gazprom in 2004, and Kaunas Heat and Power Plant to Gazprom in 2007) and the lack of any sale to a Russian investor under the rightist Homeland Union government. In contrast, both Latvian and Estonian privatizations of national gas companies to Gazprom occurred under centre right governments.

For the Lithuanian political right, particularly the conservative Homeland Union party, which at the time were the parliamentary opposition, Gazprom was not a desirable investor. Gazprom's acquisition was also controversial for the majority of centre right parties since at the time Gazprom did not own shares in any strategic assets in Lithuania (Gazprom acquired shares in the Kaunas Heat and Power Plant only in 2007, whilst it acquired a 30\% share in Stella Vitae in the mid 2000s). The Homeland Union advocated closer political and economic relations with the West and viewed Russian political and economic influence in Lithuania with concern. It is highly likely that if the conservative Homeland Union had been in power in 2000-2004 rather than the centre left coalition led by the Social Democrats, then Lietuvos Dujos would not have been privatized or Gazprom

\footnotetext{
${ }^{141}$ Junevičius cited in Bagdanavičiūtè 2000.
} 
would have acquired a smaller stake. However, in the 2000 elections the Homeland Union suffered a crushing defeat, winning only nine seats in parliament.

The terms of President Valdas Adamkus (1998-2003; 2004-2009) also coincided with the privatization period. As a nonpartisan, American-Lithuanian representing neoliberal market values, Adamkus called for the privatization to be conducted in a transparent and competitive manner and as soon as possible. He was also concerned that the Lietuvos Dujos privatization could unfold in a similar vein as the sale of the oil refinery Mažeikių Nafta to American Williams, a process that had been tainted by corruption allegations and in the end rendered the Lithuanian oil refinery unable to secure supplies of crude oil.

Meanwhile, domestic business interests that favoured closer relations with Russia and Gazprom lobbied in favour of Gazprom's acquisition of $34 \%$ of the shares of Lietuvos Dujos. Lietuvos Dujos itself, relying on Gazprom gas for operations and having a close working relationship with the company, favoured Gazprom as an investor. This is evident from the privatization provisions released by Lietuvos Dujos in 2000 which required that the prospective investor should guarantee gas supplies and potentially alternative sources of gas. ${ }^{142}$ Clearly no company other than Gazprom had the ability to supply Lithuania with gas.

Another domestic interest group in the privatization process was the gas distributor Dujotekana. Dujotekana was founded in 2001 at the outset of the privatization of Lietuvos Dujos, seemingly to play a role in that process. This is reminiscent of the founding of Itera Latvija at the outset of the privatization of Latvijas Gāze. In 2002, it was believed that Dujotekana would make a joint bid with Gazprom to acquire shares of Lietuvos Dujos, but Gazprom made an individual bid in April 2003. Nevertheless, Dujotekana was considered to have significant influence in the domestic politics of Lithuania. ${ }^{143}$ Media and analysts report that Dujotekana channeled funds to Lithuanian politicians to lobby in favour of Gazprom interests. It was particularly active in the provision of financial support to political parties in the October 2004 parliamentary elections which, however, occurred months after the finalization of Gazprom's acquisition of Lietuvos Dujos in March 2004. ${ }^{144}$ Another powerful player both in business and politics was the Russian-born Viktoras

\footnotetext{
${ }^{142}$ Junevičius in Bagdanavičiūtė 2000.

143 Janeliūnas 2009, p.212. Vitkus 2009.

${ }^{144}$ Dujotekana is likely to have made the contributions to the elections which occurred after the Gazprom deal was completed in order to have the support of all these political parties in the run up to the deal. Janeliūnas 2009, p.212.
} 
Uspaskich, a businessman who gained wealth and influence through his gas distributing business and alleged close relations with Gazprom. His offshore company Jangila, established in 1993, operated like Dujotekana and Stella Vitae, reportedly buying gas from Gazprom - at a mere eight US dollars $/ \mathrm{mcm}$ - cheaper than Gazprom sold the same gas to Lietuvos Dujos. ${ }^{145}$ Later he founded Vikonda, which is currently owned by his wife. In 2003, Uspaskich founded the Labour Party, which won the 2004 parliamentary elections and became a member of the coalition government. By the time Lietuvos Dujos was privatized in 2004, the Lithuanian gas sector was marked by powerful vested interests with close connections to Gazprom and seeming preference for the latter's control of Lietuvos Dujos.

The earlier privatization of Mažeikiu Nafta was a factor in the policy choices regarding the privatization of Lietuvos Dujos. Because the 2000 discussions regarding privatization of the enterprise followed rather soon after the 1999 privatization of Mažeikių Nafta to Williams, there were considerable 'lessons learned' and linked concerns. A number of decision makers and experts cited the frequent interruptions of the Russian crude oil pipeline to Mažeikių Nafta following its privatization to Williams as something that should be avoided with Lietuvos Dujos. ${ }^{146}$ The interruptions of oil supply were perceived as direct punishment for selling the refinery to an American rather than a Russian investor. Lietuvos Dujos was in some ways more vulnerable than Mažeikių Nafta because Lietuvos Dujos could only receive Russian gas due to the pipeline infrastructure and Mažeikių Nafta could receive alternative supplies of oil through its sea terminal at Būtingè. It was also apparent that a Western investor could not survive in the isolated Baltic energy markets. By the end of 2001, when the privatization provisions for Lietuvos Dujos were released, it was increasingly apparent that Williams would sell Mažeikių Nafta - most likely to a Russian investor. ${ }^{147}$ Thus, the sale of Lietuvos Dujos shares to Gazprom increasingly seemed the only possible outcome.

As with Latvia, another factor that influenced policies regarding the privatization of the national gas company was the broader context of relations with Russia, and particularly negotiations for a new gas supply contract. As part of the agreement to sell a $34 \%$ share to Gazprom, the Lithuanian State Property Fund had a prerequisite - the signing of a long term gas supply agreement to Lietuvos Dujos. The Lithuanian State Property Fund said in a press release that such an agreement is a major condition for the privatization of the

\footnotetext{
${ }^{145}$ Vitkus 2009, pp.25-46.

${ }^{146}$ Junevičius cited in Bagdanavičiūtè 2000.

${ }^{147}$ In 2002 Russian oil big player Yukos acquired the refinery and oil supply resumed.
} 
company, which should be carried out prior to the sale of a [34\%] packet of shares to Gazprom. ${ }^{, 148}$ In March of 2004, the Lithuanian government signed the agreement which will remain in effect until 2015. ${ }^{149}$ According to this agreement, gas was to be delivered to Lithuania at a price previously coordinated by the parties and linked to the prices set for alternative types of fuel. ${ }^{150}$

Unlike in Estonia and Latvia, the geostrategic context of the state did not appear to play a significant role in Lithuania's policy towards privatization. This may be because Lithuania in 2000-2004 found itself in a very different context than Estonia in 1993 when the latter was convulsed in state building as it privatized Eesti Gaas. It was also in a distinctly different position than Latvia in 1997 at the time of the privatization of Latvijas Gāze and processes of state consolidation. Even forthcoming EU and NATO membership did not seem to enter the Lithuanian privatization debate, nor provide Lithuania with greater leverage to resist Russian investment pressure.

The precedent of Latvian and Estonian policies in selling shares in their national gas companies to Gazprom probably had an indirect influence on Lithuania's policies towards Russian investment in Lietuvos Dujos even though Vilnius did not have any policy consultations with Riga or Tallinn. By 2000, Gazprom owned 30\% of Eesti Gaas and E.ON Ruhrgas owned 32\%. Meanwhile, Gazprom owned 25\% of Latvijas Gāze and E.ON Ruhrgas 47\%. Thus, Gazprom and E.ON Ruhrgas were the most likely contenders for Lietuvos Dujos in 2000 since they had become the main investors in the Latvian and Estonian gas companies. In the near final privatization provisions, the Lithuanian government specified it would sell a 34\% stake in (and control of) Lietuvos Dujos to a Western strategic investor, whilst Gazprom would take a 25\% stake. Gas consumers and local middlemen, meanwhile, would supply $9 \%$, and the government would retain $17 \%$. The Lithuanian government's strategy reflected the percentages Gazprom and E.ON Ruhrgas held in Eesti Gaas and Latvijas Gāze. However, the plan was not acceptable to Gazprom. The Russian monopoly demanded that it should receive no less a share of Lietuvos Dujos than the Western investor, namely, 34\%. Gazprom's new CEO, Alexey Miller, stated in October 2001 that as Lithuania's only gas supplier, Gazprom should not be treated as a mere portfolio investor but the same as a strategic Western investor. ${ }^{151}$ This

\footnotetext{
148 "Lithuania and Gazprom sign gas supply agreement".

${ }^{149}$ In 2012 the Lithuanian government used the conditions of the privatization agreement as the basis of their law suits against Gazprom.

150 "Gazprom Finalized the Deal on Lietuvos Dujos' Gas Stake".

151 "Lithuania Approves Plans for Privatisation of Lietuvos Dujos".
} 
view was related to the fact that - with regard to Eesti Gaas and Latvijas Gāze - Gazprom controlled lower share percentages when viewed as an independent actor but held the same or more shares than E.ON Ruhrgas when its close relations with Itera were taken into account. However, with the coming of the Miller management, Gazprom and Itera increasingly grew apart. The second glitch in the Lithuanian case was that the privatization provisions prohibited Itera from becoming an investor. Therefore Gazprom had to acquire a controlling share by itself. The precedents set during the privatization of Eesti Gaas and Latvijas Gāze influenced the terms of Lithuania's privatization of Lietuvos Dujos and Lithuania's policies towards Russian investment.

Western international institutions influenced Lithuanian policies as they had those of Estonia and Latvia. The privatization plan for Lietuvos Dujos was drawn up with the help of the World Bank. According to statements by Dalia Grybauskaite, Lithuania's Finance Minister at the time, the World Bank suggested that the Lithuanian government and the Western investor should together hold more than $50 \%$ of the shares in Lietuvos Dujos. In the final privatization scheme, that condition was fulfilled with E.ON Ruhrgas taking 34\% and the Lithuanian government $24 \%$ of the stakes.

\section{Summary}

In Lithuania, the domestic political environment played the most important role in determining policy options. Privatization occurred under the Social Democratic government which favoured cooperative policies towards Russia. The Social Democrats had also supported investment by Russian companies in other instances such as Mažeikių Nafta and KHPP. The Lithuanian rightist Homeland Union opposed Russian investment both when they were in government and when they were in opposition, but due to their weak position in domestic politics in 2004 , they were unable to alter the privatization provisions set out by the Social Democratic government from 2000 to 2004. The powerful vested interests in the gas sector such as Lietuvos Dujos, Dujotekana, Jangila and others with alleged close connections to Gazprom, are likely to have played an important role in Lithuania's policy choices through lobbying and potentially non-transparent funding.

Secondary factors that played an important role in Lithuanian policy choices were the precedents set by the privatizations of Eesti Gaas and Latvijas Gāze and the earlier Lithuanian sale of $\mathrm{MN}$ to American energy company Williams. Both precedents encouraged cooperative policies towards Moscow and Gazprom. The first was because Eesti Gaas and Latvijas Gāze continued to function satisfactorily and receive gas supplies when sold to Gazprom. The second was because the MN sale to a Western investor jeopardized energy supplies. A final element was the context of relations with Russia. With 
Lithuania negotiating for a new gas contract, there was pressure for a cooperative and pragmatic policy towards Gazprom.

Considering that Gazprom became a majority stakeholder (either independently or with its ally Itera) in the national gas companies of all three Baltic states, it is worth enquiring to what extent Lithuania was ever really capable of pursuing alternative policies and resisting Gazprom investment. In other words, what leverage did Gazprom have over the Lithuanian government regarding Lietuvos Dujos privatization? Cutting off gas supplies to Lithuania as punishment for privatization to a Western investor (as was done in the case of Mažeikiu Nafta) would have been much more problematic for Moscow than cutting off gas supplies to Estonia and Latvia, which do not serve as transit states. If gas were cut off to Lithuania, then it would automatically be cut off to the Russian territory of Kaliningrad which was fed by the same pipeline. Lithuania had additional levers with regard to the Kaliningrad Vilnius could threaten to cut off electricity and gas to Kaliningrad or demand that Gazprom pay market prices for the transit of natural gas from Lithuania to Kaliningrad. ${ }^{152}$ Furthermore, even if Lithuania did not sell Lietuvos Dujos to Gazprom and the latter then stopped supplying Lietuvos Dujos, Gazprom could still have supplied its partner distributing companies in Lithuania such as Dujotekana, Stella Vitae, and Vikonda. Thus Lithuanian enterprises and consumers would not have been left without gas. These levers enabled Lithuania to resist Gazprom's aspirations to acquire Lietuvos Dujos until 2004, and it is likely that Lithuania could have resisted longer if it was not for the Social Democratic government that came into power in 2000. Once privatization was selected as an option for Lietuvos Dujos, and a gas supplier was deemed by the Social Democrats as a necessary investor, Gazprom was the natural investor since other companies would not have had the gas or pipelines to supply the country. However, the future of Lietuvos Dujos is still up for revision. As noted above, Vilnius' and EU's unbundling policies will challenge the grip of Gazprom on Lietuvos Dujos.

${ }^{152}$ Drezner 1999, p.217. 


\section{BIBLIOGRAPHY}

\section{Secondary Sources}

"Antitrust: Commission opens proceedings against Gazprom". Brussels, 4 September 2012, viewed on 5 September 2012,

$<$ http://europa.eu/rapid/pressReleasesAction.do?reference=IP/12/937\&format=HTML\&ag ed $=0$ \&language $=$ EN\&guiLanguage $=$ en $>$.

Axelrod and Keohane 1986: Axelrod, Robert, and Keohane, Robert O., "Achieving Cooperation under Anarchy: Strategies and Institutions", in Kenneth A. Oye, ed. Cooperation under Anarchy, Princeton University Press, Princeton, N.J., 1986.

Bagdanavičiūtė 2000: Bagdanavičiūtè, Violeta, "Ruhrgas nori Lietuvos dujų akcijų". Verslo žinios, 31 July 2000.

"Constitution Watch". East European Constitutional Review, Vol.6, No.4, 1997.

"Consumption of energy resources in Latvia in 2010". www.csb.gov.lv, 9 May 2011, viewed on 6 January 2012, <http://www.csb.gov.lv/en/notikumi/consumption-energyresources-latvia-2010-31967.html $>$.

Čyvas 2008: Čyvas, Tomas, "Premjeras toliau teigia, jog dujų kainu reguliavimas nereikalingas". www.balsas.1t, 8 May 2008, viewed on 6 January 2012, $<$ http://www.balsas.lt/naujiena/194996/premjeras-toliau-teigia-jog-duju-kainureguliavimas-nereikalingas/rubrika:naujienos-lietuva-politika $>$.

Damulytė 2008: Damulytė, Jūratè, "Socdemai užsimojo prieš 'Leo LT? kritikuojančias partijas". www.delfi.lt, 7 February 2008, viewed on 6 January 2012, http://verslas.delfi.lt/energetics/article.php?id=15897669\&categoryID=15102910.

Drezner 1999: Drezner, Daniel W., The Sanctions Paradox: Economic Statecraft and International Relations. Cambridge University Press, Cambridge, 1999.

"Dujotekanos? čiuptuvuose - korumpuotos Lietuvos valdžios piramidè". www.balsas.lt, 22 March 2007, viewed on 6 January 2012, $<$ http://www.balsas.lt/naujiena/64156/dujotekanos-ciuptuvuose-korumpuotos-lietuvosvaldzios-piramide/rubrika:naujienos-lietuva $>$.

"EK tyrimas: SGD terminalas galetu buti statomas Estijoje". BNS, 28 June 2012, viewed on 15 August 2012, <http://m.delfi.lt/verslas/article.php?id=59020767>. 
"Energetinio saugumo pavertimas realybe atsietų 27,5 mlrd. eurų - URM". www.balsas.lt, 11 May 2009, viewed on 6 January 2012, $<$ http://www.balsas.lt/naujiena/251822/energetinio-saugumo-pavertimas-realybe-atsieitu27-5-mlrd-euru-urm/rubrika:naujienos-lietuva-politika $>$.

Findlater and Noël 2010: Findlater, Sachi, and Noël, Pierre, "Gas Supply Security in the Baltic States: A Qualitative Assessment". EPRG Working Paper, University of Cambridge, 2010 .

"Gazprom finalized the deal on Lietuvos Dujos' Stake". www.gazprom.com, 24 March 2004, viewed on 6 January 2012,

$<$ http://www.gazprom.com/press/news/2004/march/article62664/>.

Geden 2009: Geden, Oliver, ?EU Energy Policy, ? in Sprūds, Andris and Rostoks, Toms eds. Energy: Pulling the Baltic Sea Region Together or Apart? Latvian Institute of International Affairs, Riga, 2009.

Girdvainis 2012: Girdvainis, Julius, "Apsižiūrèta kad tik lietuviai dujas perka brangiai". Respublika, 16 May 2012.

http://www.respublika.1t/lt/naujienos/lietuva/lietuvos_politika/apsiziureta_kad_tik_lietuvia i_dujas_perka_brangiai/

Goldman 2008: Goldman, Marshall I., Petrostate: Putin, Power and the New Russia. Oxford University Press, Oxford, 2008.

Gotev 2012: Gotev, Georgi, "Lithuania steps forward as whistleblower in Gazprom row", 6 September 2012, viewed on 13 September 2012, http://www.euractiv.com/energy/lithuania-steps-forward-gazprom-news-514650.

Grigas 2010: Baranauskaite Grigas, Agnia, "Explaining the Policies of the Baltic states towards Russia, 1994 - 2010". Doctoral thesis, University of Oxford, Oxford, UK, November 2010.

Grigas 2012: Grigas, Agnia "Legacies, Coercion and Soft Power: Russian Influence in the Baltic States". Russia and Eurasia Programme RSP BP 2012, Chatham House, London, UK, 2012.

Grigas 2013: Grigas, Agnia, "The Politics of Energy and Memory between the Baltic States and Russia". Ashgate Publishing, London, to be published 2013.

Gudavičius 2010: Gudavičius, Stasys, "Lietuvos vadové V.Putinui kèlè duju kainu klausima". http://klaipeda.diena.lt/, 10 February 2010.

Henderson 2010: Henderson, James, "Non-Gazprom Gas Producers in Russia". OIES, 2010, http://www.oxfordenergy.org/shop/non-gazprom-gas-producers-in-russia/. 
Henderson 2011: Henderson, James, " Domestic Gas Prices in Russia - Towards Export Netback?", November 2011, <

http://www.oxfordenergy.org/?s=Domestic+Gas+Prices+in+Russia $+>$.

Henderson 2012: Henderson, James, "Is a Russian Domestic Gas Bubble Emerging?" OIES, March 2012. <

http://www.oxfordenergy.org/?s=Is+a+Russian+Domestic+Gas+Bubble+Emerging $>$.

Henderson, Pirani, and Yafimava 2012: Henderson, James, Pirani, Simon and Yafimava, Katja ;"CIS Gas Pricing: towards European netback?" in Stern, Jonathan, ed. "The Pricing of Internationally Traded Gas", Chapter 5, OIES/OUP, 2012.

http://www.oxfordenergy.org/?s=The+Pricing+of+Internationally+Traded+Gas

Iklaa 2010: Iklaa, Jaanus, "Implementing the Third Energy Package and the Climate Change Package in Estonia". European Energy Review 2010: Special Edition on the EU Third Energy and Climate Change Packages, Herbert Smith LLP, Tallinn, 2010. http://www.herbertsmith.com/NR/rdonlyres/54046A53-CFCB-438D-A1DB40E122736E48/0/7847EER2010d1Estonia.pdf

"International arbitration settles Gazprom's claims against Lithuanian Ministry of Energy". Gazprom, 31 July 2012, viewed on 15 August 2012, http:/www.gazprom.com/press/news/2012/july/article141139/.

Janeliūnas 2009: Janeliūnas, Tomas, "Lithuanian Energy Strategy and its Implications on Regional Cooperation", in Andris Sprūds and Toms Rostoks, eds. "Energy: Pulling the Baltic Sea Region Together or Apart"? Latvian Institute of International Affairs, Riga, 2009. http://www.janeliunas.lt/files/energy.pdf

Jensen 2006: Jensen, Nathan M., "Nation States and the Multinational Corporation: A Political Economy of Foreign Direct Investment". Princeton University Press, Princeton, 2006.

Kaupilla 1999: Kauppila, Laura, "The Baltic Puzzle: Russia's Policy Towards Estonia and Latvia 1992-1997". Post Graduate Thesis, University of Helsinki, Department of Social Sciences, Helsinki, 1999.

Keohane 1984: Keohane, Robert O., "After Hegemony: Cooperation and Discord in the World Political Economy", Princeton University Press, Princeton, N.J., 1984.

Kilvits, Purju, and Pädam, 2005: Kilvits, Kaarel, Purju, Alari and Pädam Sirje, "Russia's Foreign Direct Investments in the New EU Member States: The Case of the Baltic States", in Kari Liuhto, ed. "Expansion or Exodus: Why Do Russian Corporations Invest Abroad". International Business Press, New York, 2005. 
Kirkilas 2009: Kirkilas, Gediminas, ? ?Veidmainiški pagraudenimai?. www.delfi.lt, 16 December 2009, viewed on 6 January 2012, $<$ http://blog.delfi.lt/gediminas_kirkilas/6072/>.

"Kitąmet bus statomas suskystintas dujų terminalas". ELTA, 2 November 2011, viewed on 6 January 2012, <http://www.ekonomika.lt/naujiena/kitamet-bus-statomasplaukiojantis-suskystintu-duju-terminalas-15065.html $>$.

Kriukov and Moe 1996: Kriukov, Valery, and Arild Moe, "The New Russian Corporatism: A Case Study of Gazprom". The Royal Institute of International Affairs, Chatham House, London, 1996.

"Latvian - Russian Draft Border Agreement Fully Harmonized". Ministry of Foreign Affairs of the Republic of Latvia, Riga, 7 August 1997, viewed on 6 January 2012, http://www.mfa.gov.lv/en/news/press-releases/1997/aug/2137.

LeBras 2000: LeBras, Elizabeth, "Itera?s Success Raises Suspicions". St. Petersburg Times, 14 November 2000. http://sptimes.ru/index.php?cx=014092245136349118466\%3Ab_lkoylg_qw\&cof=FORID $\% 3 \mathrm{~A} 9 \&$ ie $=$ windows$1251 \& q=$ itera $\% 27 s+$ success\&sa $=$ Search\&action_id= $=15 \&$ siteurl=http $\% 3 \mathrm{~A} \% 2 \mathrm{~F} \% 2 \mathrm{Fwww} . \mathrm{s}$ ptimes.ru\%2F.

Lejin̦š 2010: Lejinšs, Ģirts, "Implementing the Third Energy Package and the Climate Change Package in Latvia". European Energy Review 2010: Special Edition on the EU Third Energy and Climate Change Packages. Herbert Smith LLP, Riga, 2010. http://www.herbertsmith.com/NR/rdonlyres/2969DFD5-3691-41C3-AB019703C0DC3ECB/0/7847EER2010d1Latvia.pdf

Lill 2001: Lill, Bruno, "Latvian Energy Sector Summary". Center for Markets in Transition, HSE, October 2001.

Lindblom 1965: Charles Edward Lindblom, "The Intelligence of Democracy: Decision Making through Mutual Adjustment", The Free Press, New York, 1965.

"Lithuania and Gazprom sign gas supply agreement". Interfax, 10 March 2004.

"Lithuania Approves Plans for Privatisation of Lietuvos Dujos". Alexander's Gas and Oil Connections, Vol.6, 7 November 2001.

"Lithuania hits Gazprom with \$1.9 billion claim", www.theguardian.co.uk, 3 October 2012. 
Loskot-Strachota and Pelczyńska-Nałęcz 2008: Łoskot-Strachota, Agata, and Pełczyńska-Nałęcz, Katarzyna, "Gazprom's Expansion in the EU: Corporation or Domination"? Centre for Eastern Studies, Warsaw, 2008.

McGregor 2002: McGregor, Caroline, "Gazprom and Itera: A Case Study in Russian Corporate Misgovernance". The Carnegie Endowment for Peace, Washington DC, 2002.

Motieka, Vaičiūnas, and Gaidytė 2008: Motieka, Egidijus, Vaičiūnas, Žygimantas and Gaidyte, Teodora "Rusijos energetiniu ištekliu tiekimo Europos Sajungai nutraukimo jvertinimas: pasekmés Rusijai ir ES". Strateginių studijų centras, Krašto apsaugos ministerija, Vilnius, 2008.

MP claims EC prefers Estonia as host to LNG terminal. Baltic Business News, 21 June 2012, viewed on 15 August 2012, <http://balticbusinessnews.com/article/2012/6/21/mpclaims-ec-prefers-estonia-as-host-to-lng-terminal $>$.

Noel, Findlater, and Chyong 2012: Pierre Noel, Sachi Findlater and Chi Kong Chyong, "The Costs of Improving Gas Supply Security in the Baltic States", EPRG Working Paper 1203, Electricity Policy Research Group, University of Cambridge, January 2012.

"NSGK išslaptino pareigūnų liudijimus (dokumentai)". www.delfi.lt, 20 March 2007, viewed on 6 January 2012, http://www.delfi.lt/news/daily/lithuania/article.php?id=12570576.

Orechovas 2007: Orechovas, Vladimiras, "Išaugusios duju kainos - nešvariu politiniu žaidimu rezultatas". www.komentaras.1t, 17 December 2007, viewed on 6 January 2012, $<\mathrm{http}: / /$ www.komentaras.lt/?p=2740>.

Pavuk 2007: Pavuk, Olga, "Energy Interview, Latvia". The Energy Course, 30 November 2007.

Pečeliūnaitė 2007: Pečeliūnaitè, Liepa, "Dujotekana' kartu su VSD išnaudoja žiniasklaida?", www.alfa.lt, 20 March 2007, viewed on 6 January 2012, $<$ http://www.alfa.lt/straipsnis/130563>.

"Pilkasis kardinolas Albinas Januška grịžta". www.balsas.1t, 1 April 2009, viewed on 6 January 2012, http://www.balsas.lt/naujiena/245929/pilkasis-kardinolas-albinas-januskagrizta/rubrika:naujienos-lietuva-politika.

Pirovska 2003: Pirovska, Margarita, "Integration of East and West European Gas Markets: Strategies in the Liberalization Context". Phd Work, CGEMP / University Paris Dauphine, Paris, France. 2003.

Riley 2009: Riley, Alan, "De-Weaponising the Energy Weapon". Memorandum in the House of Commons - Defense Committee, www.parliament.uk, 2009. 
Riley 2012: Riley, Alan, "Gazprom vs. the Commission", The Wall Street Journal, New York, NY, 11 September 2012, viewed on 13 September 2012

$<$ http://online.wsj.com/article/SB10000872396390443921504577643173700034222.html? mod=googlenews_wsj>.

Roberts 2008: Roberts, Paul, "The Seven Myths of Energy Independence". Mother Jones, May/June 2008.

"Russian Gas Deliveries to Baltic Region Halted". Izvestia, Vol XLV, No.26, 1993. "Seimas pritarẻ suskystintų gamtinių dujų terminalo statybai", alfa.lt, 12 June 2012, viewed on 15 August 2012,

$<$ http://www.alfa.1t/straipsnis/14777654/Seimas.pritare.suskystintu.gamtiniu.duju.terminal o.statybai=2012-06-12_11-32>.

Silverstein 2006: Silverstein, Ken, "The ITERA/Weldon Link: Congressman Flacked for Daughter?s Client Despite being Briefed on its Shady Practices". Harper's Magazine, October 2006.

Šimašius 2002: Šimašius, Remigijus, "Tariami ir tikri privatizuotojų paklydimai". www.lrinka.lt, 29 October 2002, viewed on 6 January 2012,

$<$ http://www.lrinka.lt/n/index.php/meniu/ziniasklaidai/straipsniai_ir_komentarai/tariami_ir tikri_privatizuotoju_paklydimai/1428>.

Šindeikis 2006: Šindeikis, Algimantas, "Kas sieja VSD, 目Dujotekaną? ir Kremlių?" Veidas, No.42, 19 October 2006, http://archyvas.veidas.lt/lt/leidinys.nr/45386931787e5.

Sloga 2008: Sloga, Gunta, "Not Becoming Russia's Wedge in Europe". Diena, 2008.

Smith 2004: Smith, Keith C., "Russian Energy Politics in the Baltics, Poland and Ukraine: A New Stealth Imperialisms"? CCIS, Washington DC, 2004.

Sprūds 2009: Sprūds, Andris, "Latvia's Energy Strategy: Between Structural Entrapments and Policy Choices", in Andris Sprūds and Toms Rostoks, eds. "Energy: Pulling the Baltic Sea Region Together or Apart?", Latvian Institute of International Affairs, Riga, 2009.

"Stella Vitae žada atnaujinti dujų tiekimą". Lietuvos rytas, 12 June 2002.

Stern 2005: Stern, Jonathan, "The Future of Russian Gas and Gazprom". OIES/OUP, 2005, http://www.oxfordenergy.org/shop/the-future-of-russian-gas-and-gazprom/.

Stern 2012a: Stern, Jonathan, ed. "The Pricing of Internationally Traded Gas". OIES/OUP, 2012, http://www.oxfordenergy.org/shop/the-pricing-of-internationallytraded-gas-ed-jonathan-p-stern/ 
Stern 2012b: Stern, Jonathan, "The Pricing of Gas in International Trade: an historical survey", in Stern 2012a.

Stern and Rogers 2012: Stern, Jonathan, and Rogers, Howard, "The Transition to HubBased Gas Pricing in Continental Europe",' in Stern 2012a.

"Stokholmo arbitražas atmetė 'Gazprom' pretenzijas Lietuvai dèl 'Lietuvos dujų' veiklos tyrimo". Lietuvos Respublikos energetikos ministerija, 31 July 2012, viewed on 15 August 2012, http://www.enmin.lt/lt/news/detail.php?ID=2235.

Stranga 1996: Stranga, Aivars, "Russia and the Security of the Baltic States: 1991-1996", in Atis Lejins and Daina Bleiere, eds. "The Baltic States: Search for Security", Riga, 1996.

Stranga 1998: Stranga, Aivars, "A Crisis in Latvian-Russian Relations March - August 1998". http://www.nato.int/acad/fellow/96-98/stranga.pdf.

Sytas 2012: Sytas, Andrius, "Gazprom atpigino dujas keletui Europos šalių, bet ne Lietuvai". Lietuvos Rytas, 17 February 2012.

"Transparency in Russia and Eurasia and Energy Security in Europe", . Seminar Summary, 5 June 2008, Chatham House, London, UK, http://www.chathamhouse.org/sites/default/files/public/Research/Russia\%20and\%20Eurasi a/050608rep.pdf.

Tvaskienė 2009: Tvaskienè, Jurga, "Grèsmès šaliai grimzta užmarštin". Lietuvos žinios, 21 January 2009.

Vilemas 2002: Vilemas, Jurgis, "Russia's Energy Policy", in Janusz Bugajski and Marek Michalewski, eds. "Toward an Understanding of Russia: New European Perspectives". Council on Foreign Relations, New York, 2002.

Vitkus 2009: Vitkus, Gediminas, "Russian Pipeline Diplomacy: A Lithuanian Response". Acta Slavica Iaponica, Tomus 26, Sapporo, 2009.

\section{Primary Sources}

"An Energy Overview of the Republic of the Estonia", 2003. U.S. Department of Energy, Washington D.C., $2003<$

http://www.geni.org/globalenergy/library/national_energy_grid/estonia/EnergyOverviewof Estonia.shtml $>$.

"Baltic Energy Market Interconnection Plan". Progress Report June 2011, European Commission, http://ec.europa.eu/energy/infrastructure/doc/20120726_3rd_bemip_progress_report_final. pdf. 
Baltic News Service (BNS) - Homepage, http://www.bns.lt/lv/.

BP 2012; "BP Statistical Review of World Energy, June 2012", $<$ http://www.bp.com/assets/bp_internet/globalbp/globalbp_uk_english/reports_and_public ations/statistical_energy_review_2011/STAGING/local_assets/pdf/statistical_review_of_w orld_energy_full_report_2012.pdf $>$.

"Development of the Lithuanian Energy Strategy after the Closure of Ignalina NPP". Lithuanian Energy Institute, Vilnius, August 2008.

Eesti Gaas - Homepage, $<$ http://www.gaas.ee/ $>$.

Eesti statistika - Homepage, http://www.stat.ee/.

Energetikos sektoriaus apžvalga. Hansabankas, December 2006.

European Commission - Homepage, $<$ http://ec.europa.eu/index_en.htm>.

Eurostat - Homepage,

$<$ http://epp.eurostat.ec.europa.eu/portal/page/portal/eurostat/home/>.

Gazprom - Homepage, <http://www.gazprom.com/>.

Gazprom Export - Homepage, <http://www.gazpromexport.ru/en/>.

Itera - Homepage, $<$ http://www.iteragroup.com/isp/go/>.

Latvijas Gāze - Homepage, <http://www.lg.lv/>.

Latvijas statistika - Homepage, $<$ http://www.csb.gov.lv/>.

Lietuvos dujos - Homepage, $<$ http://www.dujos.lt/ $>$.

"Lietuvos Respublikos elektros energijos ir gamtinių dujų rinkų metinė ataskaita Europos Komisijai". Vilnius, 2011, http://www.regula.lt/lt/publikacijos/ataskaitoseuropos-komisijai/2009_m_Elektros_ir_duju_rinkose.pdf.

Lietuvos statistikos departamentas - Homepage, $<$ http://www.stat.gov.lt/lt/>.

Lithuanian Ministry of Foreign Affairs - Homepage, <http:/www.urm.lt/>.

Lithuanian Ministry of Energy - Homepage, <http://www.enmin.lt/lt/>. 
Seminar Summary: REP 06/08: "Transparency in Russia and Eurasia and Energy

Security in Europe". Chatham House Seminar, London, 2008,

http://www.chathamhouse.org.

Statistical Yearbook of Estonia 2011. Statistics Estonia, Tallinn, 2011, $<$ http://www.stat.ee/>.

Statistical Yearbook of Latvia 1996. Statistics Latvia, Riga, 1996, $<$ http://www.csb.gov.lv/>.

Statistical Yearbook of Latvia 2008. Statistics Latvia, Riga, 2008, $<$ http://www.csb.gov.lv/>.

Statistical Yearbook of Lithuania 1996. Statistics Lithuania, Vilnius, 1996, $<$ http://www.stat.gov.lt/lt/>.

Statistical Yearbook of Lithuania 2008. Statistics Lithuania, Vilnius, 2008, $<$ http://www.stat.gov.lt/lt/ $>$.

Statistical Yearbook of Lithuania 2011. Statistics Lithuania, Vilnius, 2011, $<$ http://www.stat.gov.lt/lt/>.

\section{Interviews by the Author}

Achema management. Interview, December 2009. (1) ${ }^{153}$

Anonymous Baltic diplomat. Interview, 27 January 2010. (2)

Anonymous Baltic diplomat. Interview, 13 July 2010. (3)

Baltic and CIS energy industry insider. Interview, March 2008. (4)

EXMAR executive. Interview, February 2010. (5)Lithuanian diplomats. Interviews, Spring and Summer 2009. (6)Lithuanian Homeland Union Party member. Interview, March 2008. (7)Senior strategist of Lithuania's Homeland Union political party. Interview, June 2010. (8)

\footnotetext{
153 The numbering refers to a supplementary confidential list providing additional information on the anonymous interviews.
} 